\title{
Tulane
}

\author{
Tulane Economics Working Paper Series
}

\section{"Province-Managing-County" Fiscal Reform, Land Expansion, and Urban Growth in China}

\author{
Yongzheng Liu \\ School of Finance \\ China Financial Policy \\ Research Center \\ Renmin University of China \\ yongzheng.liu@ruc.edu.cn
}

\author{
James Alm \\ Department of Economics \\ Tulane University \\ jalm@tulane.edu
}

Working Paper 1625

December 2016

\begin{abstract}
The central government of the People's Republic of China enacted a fiscal reform known as the "Province-Managing-County" (PMC) fiscal reform in the early 2000s. This reform eliminated the prefecture city government as the intermediate layer between the province and the county, and was intended largely to improve administrative efficiency and to lessen the fiscal stress of county governments. We apply a difference-in-difference method using a panel data set of 263 cities nationwide over the period of 1999-2011 to examine how the introduction of the PMC fiscal reform affects the economic growth of the cities. Our results show that on average implementing the PMC fiscal reform moderately increases city GDP growth by around 1 percentage point. We argue that this unexpected positive growth effect of the reform is induced by the expansion of land supply of the reformed cities, which in the post-reform period have faced the need to look for revenues outside the budget system, mainly extra-budgetary funds in the form of leasing land. Our analysis provides evidence on this argument, and reveals that the reformed cities tend to expand land leasing at a speed that is 14 percent higher than the non-reformed cities. Furthermore, we show that the impacts of the reform tend to be strengthened over time following the introduction of the reform. Our results are quite robust to alternative estimation methods.
\end{abstract}

Keywords: Province-Managing-County Fiscal Reform, Land Lease, City GDP Growth, China. JEL codes: H11, H77, R11, R52 


\title{
"Province-Managing-County" Fiscal Reform, Land Expansion, and Urban Growth in China*
}

\author{
Yongzheng Liu \\ School of Finance \\ China Financial Policy Research Center \\ Renmin University of China \\ Email: yongzheng.liu@ruc.edu.cn \\ James Alm \\ Department of Economics \\ Tulane University \\ Email: jalm@tulane.edu
}

\begin{abstract}
The central government of the People's Republic of China enacted a fiscal reform known as the "Province-Managing-County" (PMC) fiscal reform in the early 2000s. This reform eliminated the prefecture city government as the intermediate layer between the province and the county, and was intended largely to improve administrative efficiency and to lessen the fiscal stress of county governments. We apply a difference-in-difference method using a panel data set of 263 cities nationwide over the period of 1999-2011 to examine how the introduction of the PMC fiscal reform affects the economic growth of the cities. Our results show that on average implementing the PMC fiscal reform moderately increases city GDP growth by around 1 percentage point. We argue that this unexpected positive growth effect of the reform is induced by the expansion of land supply of the reformed cities, which in the post-reform period have faced the need to look for revenues outside the budget system, mainly extra-budgetary funds in the form of leasing land. Our analysis provides evidence on this argument, and reveals that the reformed cities tend to expand land leasing at a speed that is 14 percent higher than the nonreformed cities. Furthermore, we show that the impacts of the reform tend to be strengthened over time following the introduction of the reform. Our results are quite robust to alternative estimation methods.
\end{abstract}

Keywords: Province-Managing-County Fiscal Reform; Land Lease; City GDP Growth; China

JEL Classifications: H11; H77; R11; R52

\footnotetext{
* This paper is supported by the National Natural Science Foundation of China (Nos. 71403276; 71533006) and the Program for New Century Excellent Talents in University (NCET-13-0573) of the Ministry of Education of China. We are grateful for helpful comments from Bo Zhao and other session participants at the 2015 Allied Social Science Association Conference, the 2015 International Workshop on Regional, Urban, and Spatial Economics in China at Tsinghua University, as well as seminar participants at Renmin University. We are especially grateful to the editor and two anonymous referees for many helpful comments and suggestions that substantially improved the paper.
} 


\section{$\underline{\text { 1. Introduction }}$}

The current tax system in China, known as the "Tax Sharing" system, has frequently and increasingly been criticized. Some concerns relate to its low administrative efficiency under a hierarchical fiscal managing system and to the very large gap between revenue and expenditure assignments at the local level (World Bank, 2002; Martinez-Vazquez et al., 2014). Indeed, many local governments, particularly county and township governments, have experienced difficulties in financing public goods and services (Luo et al., 2007). In response, the central government enacted a fiscal reform known as the "Province-Managing-County" (PMC) fiscal reform in the early 2000s. This reform was intended largely to improve administrative efficiency and to lessen the fiscal stress of county governments by eliminating the prefecture city government as the intermediate layer between province and county. The PMC fiscal reform therefore transformed the existing hierarchical fiscal managing system from a province-managing-city and citymanaging-county model to a model in which the province directly and separately manages the prefecture city and county on fiscal matters. It is believed that the removal of the potential "exploitation" of city governments will give the reformed county government more local discretion so that it will enjoy smoother fiscal transactions with provincial governments. The broad intent is to enhance administrative efficiency and local economic development.

This transformation of the landscape of fiscal structures at the city level seems likely to induce significant changes in city governments' taxing behaviors and expenditure patterns, which may in turn have effects on the economic performance of the cities, especially the economic growth of the cities. The reform-induced decrease of city revenues may induce city governments to look for revenues outside the budget system, ${ }^{1}$ mainly extra-budgetary funds in

\footnotetext{
${ }^{1}$ Under the current highly centralized political system in China, local government officials are promoted or demoted by the upper level governments based on criteria strongly associated with economic performance. In trying to stay
} 
the form of leasing lands for business, which are at present the most important source of extrabudgetary revenues for local governments in China. The expansion of land availability may thus lead to a higher rate of urban economic growth (Lichtenberg and Ding, 2009; Ding and Lichtenberg, 2011). However, other research has raised the concern that the PMC fiscal reform may reduce the necessary resources for the development of the city, with negative impacts on the urbanization process in China, because the reform eliminates the authority of city governments to exploit county revenues, to assign excessive expenditure responsibilities to the county, and to withhold fiscal transfers from provincial governments (Zheng, 2009).

The existing literature does not provide any empirical evidence supporting these arguments, mainly focusing on the impact of the reform on the performance of county governments and largely ignoring the effects on city governments. ${ }^{2}$ Identifying the potential impacts of the PMC fiscal reform on the cities, especially its growth impacts, is essential for a systematic evaluation of the reform. This is our purpose here.

We first build a simple theoretical model to frame the possible linkage from the introduction of the PMC fiscal reform to the expansion of urban land leasing. This model suggests a "direct effect" of the PMC fiscal reform on the GDP growth of the cities via its impact on land as a direct production factor, as well as an "indirect effect" via its impact on the inflow of capital induced by the expansion of urban land use. We then use panel data that covers 263 prefectural-level cities from 1999 to 2011 to test these predictions. We find that the PMC fiscal reform has indeed improved overall city GDP growth and that this growth appears to come at the

ahead of the professional career ladder, local government officials in general have a strong incentive to maximize their revenues that could be used to support local economic growth more quickly.

${ }^{2}$ For example, some recent researchers have pointed to the reform's effectiveness in strengthening county government fiscal capacity and promoting county economic growth (Cai and Huang, 2010; Liu et al., 2011; Zheng et al., 2011). Others provide evidence that the reform may have reshaped county governments' patterns of public spending toward a higher level of productive expenditure and a lower level of welfare expenditure (Liu et al., 2012; Wang et al., 2011). 
expense of expanding "land grab" behaviors of local governments. Moreover, our results suggest that the impacts of the reform have been increasing over time after the reform and also that the effects of the reform tend to be stronger for "poor" cities.

Our paper is related to prior literature explaining urban economic growth in China, which has been the most important component of China's overall economic growth in recent decades. Much of this literature has emphasized the roles of productive and institutional factors (e.g., the stocks of physical and human capital, openness to trade, the size of the labor force, agglomeration economies, private sector development, and technological changes) in China's economic growth (Berthelemy and Demurger, 2000; Chen and Feng, 2000; Zhang, 2001; Lin and Song, 2002; Anderson and Ge, 2004; Gao, 2004; Phillips and Shen, 2005; Au and Henderson, 2006; He and Fan, 2010; He et al., 2014). ${ }^{3}$ These studies have typically found that such factors as foreign direct investment (FDI), infrastructure investment, human capital investment, the decline of the state sector, industrial structure, dynamic externalities, and the overall economic transition in China have contributed significantly to per capita GDP growth of the cities.

More closely related to our study are two other stands of literature. The first strand concerns the role of institutional reforms in urban economic growth, and emphasizes that administrative and fiscal decentralization during China's transition period has successfully fostered strong fiscal and political incentives for local government to promote local economic development. Such local development has in turn been seen as fundamental for China's overall

\footnotetext{
${ }^{3}$ For example, Lin and Song (2002) use a sample of 189 large and medium-sized Chinese cities from 1991 to 1999 , and find evidence that foreign direct investment, infrastructure investment, and human capital investment have contributed to per capita GDP growth of the cities. Similarly, Anderson and Ge (2004) conclude that a decline of the state sector and an increase in openness to FDI have accelerated urban economic growth in 220 Chinese cities during the period 1990-1999; their results also lend support to the influence of other factors identified in the literature such as geography, industrial structure, and human capital accumulation. He and Fan (2010) employ data on two-digit manufacturing industries for prefecture-level cities in China during the years 2000-2005 to examine the determinants of city-industry growth in China. They find that dynamic externalities have had significant impacts on city-industry growth in China and that the economic transition has created conditions that facilitate the role of dynamic externalities in stimulating city-industry growth.
} 
economic growth. For example, see Zhang and Zhou (1998), Lin and Liu (2000), Jin et al. (2005), Gordon and $\mathrm{Li}$ (2011), and $\mathrm{Xu}$ (2011). The second strand highlights the importance of land expansion in urban economic growth. Under the current Chinese decentralization system, land use has long been seen as a vital instrument both for local governments to compete for foreign and domestic capital and for these local governments to increase local revenue to promote local economies. For example, Liu et al. (2008) find evidence that land leasing significantly contributes to local GDP growth, and Ding and Lichtenberg (2011) find that land availability is positively associated with urban economic growth, with a larger impact on economic growth than domestic and foreign investment, labor supply, and government spending. More recently, He et al. (2014) find that land acts both as a simple factor of production but also as a successful strategic tool to attract foreign investments and sustain infrastructure investments, indirectly triggering urban economic growth in China. Also, see Tao et al. (2010), Liu and MartinezVazquez (2014), and Huang et al. (2015).

The rest of the paper is organized as follows. Section 2 provides a brief overview of the PMC fiscal reform in China. Section 3 establishes a simple model to highlight the potential impacts of the PMC fiscal reform on land expansion and urban GDP growth. Section 4 introduces and discusses the data. Section 5 sets up the empirical methodology and presents the main results and the robustness tests. Section 6 discusses the dynamic and heterogeneous effects of the reform. The last section concludes.

\section{A Brief Overview of the PMC Fiscal Reform in China}

\subsection{Institutional Background}


The People's Republic of China has maintained a highly centralized political system with a homogeneous but "hierarchical" structure of governance since its formation in 1949. Currently, there are five levels of governments in China. Starting with highest, these levels are: the centre, provinces, prefectures and prefecture-level cities (hereafter, cities), counties, and townships. Under the hierarchical system, each subnational level of government is wholly subordinate to the next higher order of government, and so the intergovernmental fiscal relationships are typically defined and implemented between the government at the corresponding level and its immediate upper level of government (i.e., centre-managing-province; province-managing-city; citymanaging-county; county-managing-township).

Nevertheless, the hierarchical system is accompanied by a weak institutional setup of fiscal arrangements. The current tax sharing system has for the first time in history clearly defined the revenue assignments between the central and provincial governments, but it has also left open an unclear assignment of expenditure responsibilities among the different levels of governments (Xu, 2011; Liu and Martinez-Vazquez, 2014). Also, sub-provincial fiscal arrangements are not formalized by any laws or regulations. Instead, the central government grants provincial governments the discretion to set up their own intergovernmental fiscal relationships within the provinces. Practically, provincial governments have mostly followed the hierarchical fashion to determine their fiscal relationships with city governments, and have authorized city governments to specify their relationships with county governments (MartinezVazquez et al., 2008; Liu et al., 2014). Thus this institutional setup implies many different fiscal arrangements at the sub-provincial level that depend on the specific province.

Even so, two essential features are common in virtually all provinces. First, the multilayer government structure seems to have hampered administrative efficiency. The intermediate 
layers of governments, usually city governments, tend to act as a "grabbing" rather than a "helping" hand, which distorts top-down communications and bottom-up reporting between the upper and lower levels of governments. Most often, in order to pursue their own interests, city governments have an incentive to retain the authority and the resources given them from the central or provincial governments that otherwise should be directed to county governments. Because of this, lower-tiered governments (i.e. county and township governments) have lost their independence in making appropriate policies for their jurisdictional development and in implementing them on the basis of local conditions. This expansion in city government discretion has also made it more difficult for the policy objectives of the centre to be realized at lower sub-national level even if the central government intervenes in local issues at the county and sometimes even at the township government levels (Martinez-Vazquez et al., 2008).

Second, a large gap seems to have emerged between revenue and expenditure assignments at the local level. In line with the twin objectives of raising the central government's revenues and strengthening the control of the central government in the fiscal system, the "Tax Sharing" system reform in 1994 successfully recentralized revenues to the central level via a clear classification of central taxes, local taxes, and shared taxes (Jin et al., 2005; Qiao et al., 2008). A parallel centralizing trend of revenues appears to be occurring at the sub-national levels as well, with increasing revenue shares at the provincial and city levels at the expense of county and township shares. By contrast, expenditure assignments at the different levels of government are today largely what they were decades ago under the planned economy, which assigned subnational governments (especially county and township governments) excessive expenditure responsibilities that are not consistent with much international practice. For instance, city and county governments account for all expenditure on unemployment insurance, social security, and 
welfare, and county and township governments together provide 70 percent of budgetary expenditures for education and nearly three-fifths of those for health (World Bank, 2002). This large gap between revenue and expenditure assignments has led to mounting fiscal pressures for financing public goods and services at local levels. In response to these pressures, local governments have been forced to look for revenues outside the budget system, mainly in the form of extra-budgetary funds.

\subsection{The PMC Fiscal Reform}

As a response to these concerns and to strengthen the role of county governments in improving local governance, the central government launched the so-called PMC fiscal reform in the early 2000s, which eliminated the previous fiscal relationship between city and county governments and replaced it with a direct fiscal relationship between provincial and county governments. ${ }^{4}$ According to the regulations of the Ministry of Finance, the PMC fiscal reform had several main features. ${ }^{5}$ First, revenue assignments and expenditure responsibilities must be clearly defined among provinces, cities, and counties. On the basis of these assignments, city governments are not allowed to shift any of their expenditure responsibilities to their own county governments (and vice versa). Second, fiscal transfers, tax rebates, and other subsidies must be allocated separately and directly to cities and counties by provincial governments. Any applications from cities and counties for additional ad hoc transfers have to be sent directly to provincial governments, and these allocations must be evaluated and allocated directly by provincial governments. City governments may continue to make transfers to county

\footnotetext{
${ }^{4}$ Besides the PMC fiscal reform, another reform of China's government administrative system in 2003, the so-called "County-Power-Expansion" (CPE) reform, aimed to empower county governments with more authority in the management of economic matters. However, unlike the PMC fiscal reform (which had homogeneous reform policies across different reformed provinces), the CPE reform policies varied substantially across the reformed provinces. As a result, we focus exclusively on the PMC fiscal reform, for which the uniform reform rules facilitate studying the net impacts and the underlying mechanisms of the reform without other confounding factors.

${ }^{5}$ See "Opinions of the Ministry of Finance on Boosting the Fiscal Reform of "Province-Managing-County", available online at http://www.lawinfochina.com/law/display.asp?db=1\&id=8023\&keyword=Counties .
} 
governments, but these transfers must go through the provincial governments' budget accounts. Third, city and county governments must separately and independently compile their own annual budgets and final financial reports. Fourth, provincial governments must set up separate and independent accounts to manage all fiscal fund transactions between provinces and cities and also between provinces and counties, and any kinds of fiscal fund transactions between cities and counties must be abolished. In addition, provincial governments must directly determine the revenue-sharing schemes between cities and counties. Finally, annual settlements of any kinds of financial accounts must be directly conducted between provinces and cities and also between provinces and counties. If any transactions remain to be settled between cities and counties, they have to go through the provincial governments.

The PMC fiscal reform was formally initiated in some provinces around 2004, and the reform was widely carried out across the nation following this. By the end of 2009, 22 provinces in China had commenced reform on a pilot basis (Liu et al. 2011). ${ }^{6}$ The central authority that led the PMC fiscal reform is China's Ministry of Finance (MOF), and the MOF has specified that provincial governments should "...largely incorporate counties that produce a large amount of grain, oil plants and cotton into the reform with priority". Even so, the MOF generally leaves a large scope of discretion for the provinces to determine the detailed procedure of the reform within their territories by explicitly stating that "...all localities shall, in accordance with the relevant conditions such as level of economic development and infrastructure conditions,

\footnotetext{
${ }^{6}$ Zhejiang province is an exception, where the fiscal PMC model has been maintained since the every beginning of the establishment of the country in 1949.

${ }^{7}$ The underlying reason for this regulation is to make sure that the policy can be better extended to the neediest agricultural counties where fiscal stress has been most severe in the pre-reform period.
} 
determine the modes, steps and processes of reform and avoid the approach of 'one-size-fitsall'", 8

Indeed, the provinces exhibit much variety in terms of reform modes, time, selection criteria, and processes. For instance, the provinces of Heilongjiang and Jiangsu pursued a "bigbang" approach, implementing the reform provincial-wide in the initial year of the reform, instead of a more gradual approach used by the majority of other provinces. Also, the provinces of Jiangxi and Shanxi made it clear in their official documents that the initial set of the reformed counties were those identified national poverty counties, while provinces like Shaanxi combined the poverty countries in the initial set of the reform counties with some richer counties. Some other provinces simply listed the counties that were included in the reform without giving explicit information about their selection criteria. Other provinces generally indicated that they followed the guiding principle of the MOF to give the larger priority to larger agricultural counties.

In line with the policy objectives, the implementation of the PMC fiscal reform successfully increased counties' fiscal capacities, and so improved their abilities to provide public goods and services. At the same time, the PMC largely reshaped the landscape of the fiscal balance sheets at the city level. It was expected that city revenues would fall significantly, for several reasons. One factor was the termination of a city government's authority in setting specific schemes of revenue assignments between cities and counties, which had been usually seen to be designed in a way favoring city interests before the reform; an additional factor was city government discretion in withholding (or embezzling) fiscal transfers from the central or provincial governments, transfers that were supposed to be directed to county governments.

\footnotetext{
${ }^{8}$ These quoted regulations are stated in the official document "Opinions of the Ministry of Finance on Boosting the Fiscal Reform of Province-Managing-County”, issued by the MOF as a guiding file for the reform.
} 
However, city expenditure responsibilities are now clearly regulated by provincial governments, and the ability of city governments to shift part of their expenditure responsibilities to county governments is completely cut off.

Overall, then, it is expected that city governments will experience a shortfall in revenue sources, along with an increase in expenditure responsibilities. As a result, it seems likely that city governments will seek other possible revenues outside the budget system to fill the gap generated by the PMC fiscal reform.

\subsection{Land Lease as a Source of Local Government Revenue}

Over the years since the tax-sharing system reform in 1994, the recentralization of revenue assignments and the weakness of revenue bases have led local governments to experience mounting fiscal pressures for financing their expenditure needs, especially for infrastructure investment and social service provision. These have added to the local incentives to expand collection of extra-budgetary revenue by increasing local land lease. ${ }^{9}$ Local governments were provided with the opportunity to exploit land as a source of revenue because the 1994 fiscal reform grants subnational governments a great deal of discretion to act as entrepreneurs in the local land market and allows them to keep all the land-leasing revenues they mobilize (Peterson, 2006; Nitikin et al., 2012). Figure 1 provides an overview of the quantitative importance of land lease revenue as a source of subnational government revenues. In China as a whole land lease revenue grew from less than 10 (6) percent of total subnational government budgetary revenues (expenditures) in 1999 to 61 (35) percent of total subnational government budgetary revenues (expenditures) in 2011. In 2011, revenues based on land lease amounted to 3212.6 billion RMB,

\footnotetext{
${ }^{9}$ In China, local governments maintain ownership of the land and offer land use rights in the form of ground leases that allow a developer to build on the land (Anglin et al., 2014).
} 
compared to total budgetary revenues (expenditures) of 5254.7 (9273.3) billion RMB for all levels of subnational governments.

The extensive expenditure needs of local governments and their monopoly on land decision-making have made land lease revenue an especially attractive revenue source. Given this, the PMC-induced decrease of city revenue and a potential increase of expenditure responsibilities are likely to motivate city governments to further expand land leasing behaviors to fill the gap. ${ }^{10}$

\section{Theoretical Considerations}

In this section we build a simple model to highlight the incentive effects of the PMC fiscal reform on urban land expansion, which in turn contributes to the output growth of the city districts with both direct effects and indirect effects.

In accordance with the Chinese institutional structure, consider the land expansion decision of city $i$. The physical structure of city $i$ consists of urban districts and its affiliating counties, and city government officials are assumed to choose the amount of land converted from agricultural to urban use by requisitioning agricultural land (denoted $L$ ) to the urban districts. Let $C(L)$ be the cost/compensation for converting agricultural land to urban use. Given the fixed total stock of agricultural land in a city, this cost is increasing in the amount of converted land at an increasing rate, so that $C^{\prime}(L)>0$ and $C^{\prime \prime}(L)>0$, where primes denote derivatives. The urban government receives conveyance fees $V(L)$ from leasing land use rights to business users, and we assume that $V(L)$ is increasing and concave in the amount of land lease $L$.

\footnotetext{
${ }^{10}$ As demonstrated by Lichtenberg and Ding (2009), incentive-based fiscal and government reforms in China have given rise to land conversion decisions of local governments and long run urban expansion of the Chinese cities.
} 
Economic activity in the urban districts is measured by aggregated outputs, and is assumed to be an increasing and concave production function. Specifically, the aggregate production function $F()$ is given by the standard Cobb-Douglas form, or:

$$
F(K, L)=A K^{\alpha} L^{\beta},
$$

where $K$ is the amount of capital invested in the urban districts, $L$ is the amount of urban land, $A$ is the technology parameter that reflects the productivity of the city, and parameter restrictions are $\alpha>0, \beta>0, \alpha+\beta<1$, and $A>0 .{ }^{11}$

Capital is assumed to be perfectly mobile across regions, so that its net return in all regions is equalized at the given economy-wide net return to capital $(r)$; that is:

$$
(1-t) \frac{\partial F}{\partial K}=r
$$

where $\frac{\partial F}{\partial K}$ denotes the marginal product of capital and $t$ is the ad valorem tax rate on output in city $i$, fixed and coordinated by the central government for all $i .{ }^{12}$ Using equation (1), we solve (2) for the capital allocated in city $i$ to obtain:

$$
K=\left(\frac{1}{r}(1-t) A \alpha L^{\beta}\right)^{1 /(1-\alpha)} .
$$

Equation (3) implies that $\frac{\partial K}{\partial L}>0$ and $\frac{\partial^{2} K}{\partial L^{2}}<0$.

City government revenue is derived from three sources: the taxes derived from aggregated outputs of urban districts, $t F(K, L)$; the land conveyance fees mentioned above, $V(L)$; and the extra revenue extracted from its affiliated counties, denoted $G .{ }^{13}$ Thus, by design the introduction of the PMC fiscal reform enters the model by reducing the size of extra revenue, $G$.

\footnotetext{
${ }^{11}$ For analytical convenience, other fixed factors such as labor are normalized to unity and so not included in the production function, as reflected in the assumption that $\alpha+\beta<1$.

${ }_{12}$ Tax legislation is highly centralized at the central level in China.

${ }^{13}$ A typical way for the city government to achieve this is to withhold (or embezzle) fiscal transfers from the central government or from provincial governments that are supposed to be directed to county governments. See section 2 for a more detailed discussion of institutions.
} 
The objective of city officials is to choose land conversion $L$ so as to maximize the utility obtained from local fiscal expenditure $E$, net of the cost $C(L)$ for converting agricultural land to urban land use; that is:

$$
\operatorname{Max}_{L}[U(E)-C(L)]
$$

where $U(E)$ is the utility function, with $U^{\prime}(E)>0$ and $U^{\prime \prime}(E)<0$. By assuming a balanced budget constraint for the city government, we have that $E=t F(K, L)+V(L)+G$. Substituting for $E$ in equation (4), the optimal choice of city government is determined by the usual first order condition, or:

$$
\frac{\partial W}{\partial L}=\frac{\partial U}{\partial E}\left[t\left(\frac{\partial F}{\partial K} \frac{\partial K}{\partial L}+\frac{\partial F}{\partial L}\right)+\frac{\partial V}{\partial L}\right]-\frac{\partial C}{\partial L}=0
$$

Denoting $\varphi=t\left(\frac{\partial F}{\partial K} \frac{\partial K}{\partial L}+\frac{\partial F}{\partial L}\right)+\frac{\partial V}{\partial L}=t\left(\frac{r}{1-t} \frac{\partial K}{\partial L}+\frac{\partial F}{\partial L}\right)+\frac{\partial V}{\partial L}>0$ and taking the derivation of $\frac{\partial W}{\partial L}$ with respect to $L$ and $G$, respectively, we obtain:

$$
\begin{aligned}
& \frac{\partial^{2} W}{\partial L^{2}}=\frac{\partial^{2} U}{\partial E^{2}} \varphi^{2}+\frac{\partial U}{\partial E} \frac{\partial \varphi}{\partial L}-\frac{\partial^{2} C}{\partial L^{2}}<0, \\
& \frac{\partial^{2} W}{\partial L \partial G}=\frac{\partial^{2} U}{\partial E^{2}} \varphi<0,
\end{aligned}
$$

where $\frac{\partial \varphi}{\partial L}=t\left(\frac{r}{1-t} \frac{\partial^{2} K}{\partial L^{2}}+\frac{\partial^{2} F}{\partial L^{2}}\right)+\frac{\partial^{2} V}{\partial L^{2}}<0$. Finally, applying the Envelope Theorem to equation (5), we have that:

$$
\frac{\partial L}{\partial G}=-\frac{\frac{\partial^{2} W}{\partial L \partial G}}{\frac{\partial^{2} W}{\partial L^{2}}}=-\frac{\frac{\partial^{2} U}{\partial E^{2}} \varphi}{\frac{\partial^{2} U}{\partial E^{2}} \varphi^{2}+\frac{\partial U \partial \varphi}{\partial E \partial L}-\frac{\partial^{2} C}{\partial L^{2}}}<0
$$

that is; $L$ and $G$ are negatively associated, so that any decrease in extra revenue $G$ from the PMC fiscal reform will increase the amount of urban land $L$. This result from equation (8) is summarized in the following testable implication for the effect of the PMC fiscal reform:

Proposition 1: With the reduction of the extra revenue extracted from its affiliated county governments after the PMC fiscal reform, the city government will tend to expand by converting agricultural land to urban land use. 
Further, given the production function in equation (1) and the capital allocation rule of equation (3), the expansion of urban land use also suggests a "direct effect" and an "indirect effect" of the PMC fiscal reform on urban GDP growth. First, there is a "direct effect" on growth via the expansion of urban land use as a production factor; that is, an increase in $L$ is associated via the production function in equation (1) with an increase in output. Second, there is an "indirect effect" on growth via the inflow of capital that is induced by the expansion of urban land use (i.e., equation (3)), again through the production function of equation (1). This prediction is consistent with the argument that land may trigger economic growth directly as a factor of production or through other indirect channels such as attracting FDI (He et al., 2014). In the subsequent sections, we test for these effects empirically.

\section{Data}

Our panel dataset covers 263 prefectural-level cities between 1999 and 2011. Table 1.A provides a detailed definition and sources of all the variables, and summary statistics for overall sample and subsamples for the reformed and non-reformed cities are given in Table 1.B. Below, we explain some key information about the dataset in further detail.

Since the nature of the PMC fiscal reform is to break down the fiscal relationship between the prefecture-level city governments and their former subordinated county governments, identification of the impacts of the PMC fiscal reform on city governments needs to focus exclusively on the level of urban/city districts of the city, which are under the direct control of city government regardless of the reform. In other words, the basic unit of our analysis is the city aggregation of all its urban districts, excluding its belonging counties. ${ }^{14}$ Most of our

\footnotetext{
${ }^{14}$ Note that a typical prefecture-level city in China is composed of urban districts (i.e., " $q u$ ") and counties (i.e., “xian").
} 
data are obtained from various issues of the China City Statistical Yearbook, such as city GDP growth rate, GDP per capita, capital investment, population, government expenditure. The land lease data come from various issues of the China Land and Resources Yearbook, which covers annual land lease cases for prefecture-level cities.

Our key variable of interest is a dummy variable for the introduction of the PMC fiscal reform. This variable is assembled manually by looking into the official documents released by each provincial government on implementing or enlarging the PMC fiscal reform within provinces. ${ }^{15}$ These official documents generally highlight the background of the reform and explicitly lay out a detailed list of counties that will be included in the reform. Since the reform was implemented on a pilot basis in every province, it is usually the case that each province gradually expands to include different groups of counties in the reform across years. We thus collect this information for all provinces, and we then create for every county a dummy variable for whether the PMC fiscal reform has been implemented in the county in each year. Finally, we aggregate this information to the city level to create the dummy variable for the introduction of the PMC fiscal reform at the city-level, which equals 1 if at least one of a city' subordinated counties has implemented the PMC fiscal reform in a particular year and 0 otherwise. Figure 2 displays the number of cities that have implemented the PMC fiscal reform and their cumulative percentage in each year. As noted before, the Zhejiang province is the only province that has long maintained the fiscal PMC model over the entire historical period of the new China, which is reflected in Figure 2 by the 11 cities in this province that are indicated as reformed cities before year 2004. Excepting these cities, Figure 2 clearly shows that year 2004 was the start of the recent PMC fiscal reform in China. After that, the reform gradually spread to other parts of

\footnotetext{
${ }^{15}$ These official documents are usually with the title of "Circular of the People's Government of X Province Concerning the Implementation of 'Province-Managing-County' Fiscal Reform" or "Circular of the People's Government of X Province Concerning the Expansion of the Scope of 'Province-Managing-County' Fiscal Reform".
} 
the country, so that by the end of 2011, 65 percent of the Chinese cities have implemented this reform. Among these reformed cities, 34 cities were included in the reform in year 2004, 17 cities were in year 2005, 9 cities were in year 2006, 77 cities were in year 2007, and another 68 cities were included between years 2008-2011. Table 2 shows that the reform was initially adopted in four provinces in 2004 , of which three of them were located in the middle region of the country (i.e., Anhui, Henan, and Hubei). By the end of 2011, the reform had been widely adopted across the nation, except in a few remote and mostly minority (autonomous) provinces including Inner Mongolia, Ningxia, Tibet, and Xinjiang.

Figures 3 and 4 provide an overview of the evolution of average city GDP growth and land expansion in the Chinese cities over time, classified by the groups of reformed cities and non-reformed cities. In both figures, the solid lines reflect the average value for the cities that have ever implemented the PMC fiscal reform between 1999 and 2011. As a point of comparison, the dashed lines depict the corresponding average value across cities that have not implemented the reform by the end of 2011, and the vertical dashed line represents year 2004, which is the first year that the reform was introduced in some cities. The trends for the two group cities are quite comparable in both figures. While Figure 4 reveals a persistent tendency of higher land leasing in the reformed cities than in the non-reformed cities, especially for the years after 2004, the trends of average city GDP growth are more or less close to each other in Figure 3, suggesting a less visible effect of the reform. ${ }^{16}$

However, it is important to remember that these figures only offer descriptive information about average city GDP growth and land expansion. They do not control for important the differences across cities and years that are included in our formal regression

\footnotetext{
${ }^{16}$ In addition, other characteristics are relatively comparable for the reformed cities and the non-reformed cities, as shown in Table 1.B.
} 
models. In addition, for the group of reformed cities (i.e., the solid lines in the figures), a majority of them introduced the reform in different years after 2004, which complicates identification of the possible observable policy impacts of the reform. Accordingly, the next section presents our methodology for measuring these impacts.

\section{The PMC Fiscal Reform and its Impact on City GDP Growth}

\subsection{Econometric Specification}

We exploit the fact that the PMC fiscal reform was introduced in different cities and years, to estimate its causal impact on urban GDP growth in reformed and non-reformed cities. Specially, we estimate a difference-in-difference (DID) or, more generally, a fixed-effects model of the form:

$$
y_{i t}=\alpha+\beta P M C_{i t}+\gamma X_{i t}+\eta_{i}+\psi_{t}+\varepsilon_{i t}
$$

where the dependent variable $\left(y_{i t}\right)$ is the GDP growth rate of the urban districts of city $i$ at year $t$, $X_{i t}$ includes various control variables, $\eta_{i}$ is the time-invariant and city-specific effect for city $i$, $\psi_{t}$ is a set of year dummies, and $\varepsilon_{i t}$ is an i.i.d. error term. $P M C_{i t}$ is the variable of interest, a dummy variable indicating the implementation of the PMC fiscal reform in city $i$ at year $t$; that is, $P M C_{i t}$ equals 0 for years before the PMC fiscal reform was introduced in a city, and equals 1 for the first year and all the subsequent years of the PMC fiscal reform. Since recent studies demonstrate that pervasive serial correlation in DID models may produce severely downwardbiased standard errors (Bertrand et al., 2004), we use Huber-White standard errors clustered at the city-level throughout.

The coefficient $\beta$ is our primary coefficient of interest. In order for this coefficient to be an unbiased estimate of the effects of the PMC fiscal reform on urban GDP growth, the key 
identifying assumption is that the change in urban GDP growth over time in the non-reformed cities is an unbiased estimate of the counterfactual. While we cannot directly test this assumption, one way to examine the validity of this assumption is to see if the never reformed cities and the eventually reformed cities follow similar trends in the pre-treatment time period. Following Galiani et al. (2005), we estimate a modified version of equation (9) in which we used a fixedeffects model to regress the outcomes under study (i.e., the urban GDP growth and the land lease variable, respectively) on a vector of year dummies interacted with eventual treatment status and a set of control variables, time variant city effects, and year effects. We only use observations from the five years in the pre-treatment period (i.e., 1999-2003). Tables A1 and A2 in the Appendix show the results of these regressions. The coefficients on the interaction terms are insignificant in each year, and thus we cannot reject the hypothesis that urban GDP growth (or land expansion) in these two groups of cities in our sample (e.g., never reformed and eventually reformed) had identical time trends during the pre-treatment periods.

As control variables $X_{i t}$, we include factors typically found to be significant in determining economic growth, as well as variables for which data are available at the city-level in China. These variables include: land availability, the capital investment rate, the foreign direct investment (FDI) rate, the population growth rate, real GDP per capita, economic structure, economic agglomeration, inflation, and government expenditure. Land availability is captured by the total amount of land leasing by city governments (in log form). The capital investment rate and the FDI rate are measured as the ratio of total fixed capital investment to GDP and the ratio of FDI to GDP, respectively; along with the population growth rate, these variables are usually treated as the fundamental determinants of economic growth, as modeled in section 3. Real GDP per capita is included to capture a catching-up effect in cities with lower income. Economic 
structure is proxied by the share of agricultural sector in total GDP, which reflects the industrialization level of the cities. ${ }^{17}$ The presence of agglomeration economies signals a set of favorable conditions for urban economic growth, such as cutting production and transportation costs and giving rise to increasing return to scale. Following the literature, we use urban population density to measure the agglomeration economy of the city districts (Ciccone and Hall, 1996; He, 2002). Inflation is measured using the consumer price index at the provincial level. ${ }^{18}$ Inflation may reduce the level of business investment and the overall efficiency with which productive factors are put to use, resulting in a lower rate of economic growth. Government expenditure, captured by the ratio of total government expenditure to GDP, is expected to be positively associated with economic growth, given that Chinese governments have been actively involved in promoting the growth of the economy.

\subsection{Basic Results}

As predicted by our theoretical model, the PMC fiscal reform potentially induces an expansion of urban land use, which promotes urban GDP growth via a direct effect (i.e., land as a production factor) and an indirect effect (i.e., the induced inflow of capital). A confirmation of this prediction implies that the quantitative effect of the PMC fiscal reform in equation (9) will be reduced (i.e., $\hat{\beta}$ becomes smaller) once controls for urban land use and capital inflow are introduced. To test this, we add to the basic specification of equation (9) different control variables continuously, with particular focus on the changes of the estimated coefficient of the PMC fiscal reform.

\footnotetext{
${ }^{17}$ As discussed in section 2, the selection of the PMC reform may not be purely random but based on some local characteristics. The inclusion of real GDP per capita and the share of agricultural sector in total GDP also reduces possible selection bias.

${ }^{18}$ Data for inflation are not available at the city level.
} 
The basic results are presented in Table 3. Across all five regressions, we find a positive and statistically significant coefficient for the introduction of the PMC fiscal reform, indicating that the reformed cities tend to experience a higher rate of economic growth than the nonreformed cities. Consistent with our theoretical predictions, the magnitudes of the coefficients of the PMC fiscal reform indeed appear to be diminishing after we gradually add the land availability and capital inflow variables (i.e., capital investment rate and FDI rate) into the model in columns (3) to (5), supporting our argument of the land expansion as one of the sources through which the PMC fiscal reform exerts impacts on city GDP growth. ${ }^{19}$ Quantitatively, the introduction of the PMC fiscal reform on average moderately increases city GDP growth by around 1 percentage point.

The results for the control variables are mostly consistent with those obtained in the growth literature. Urban land use, capital investment, FDI inflow, economic agglomeration, and government expenditure are positively and significantly correlated with urban growth, confirming the traditional wisdom on treating these variables as important driving forces of economic growth. GDP per capita is negative and significant, which is consistent with the assumption of the conditional convergence of economic growth. The share of agricultural sector in GDP is negatively associated with city GDP growth. Inflation has a negative and significant coefficient, consistent with the hypothesis that inflation increases investment uncertainty, and therefore reduces economic agents' incentives to invest. While population growth has a consistent negative coefficient, it is not statistically significant.

\footnotetext{
${ }^{19}$ Note that, even after controlling for the land leasing variable and the capital inflow variables in the specifications, the PMC reform still has a positive effect on city GDP growth. This result suggests that there may exist other channels through which the PMC reform affects the city GDP growth, even aside from the land expansion channel that we identify below. A possible additional channel may come from the fact that the PMC reform brings more fiscal resources and authorities to the county governments and so promotes county economic development, which in turn exerts positive spillover effects on the GDP growth of city districts. An examination of all the possible channels is beyond the scope of this paper.
} 


\subsection{The Source of the PMC Fiscal Reform's Positive Effect on City GDP Growth}

Our finding of a positive effect of the PMC fiscal reform on city GDP growth may surprise critics of the reform (e.g., Zheng, 2009), as they usually believe that city governments are the "victim" of the reform. However, as discussed earlier and modeled in section 3, the PMC fiscal reform may have given city governments an incentive to expand their land leasing behaviors in order to replace the revenue losses, a result that we identified in our previous analysis as a positive contributing factor for city GDP growth.

In order to test this hypothesis and so to clarify the source through which the PMC fiscal reform positively affects city GDP growth, we form the following DID model:

$$
l_{i t}=\alpha+\beta P M C_{i t}+\gamma Z_{i t}+\eta_{i}+\psi_{t}+\varepsilon_{i t},
$$

where the dependent variable $l_{i t}$ is the $\log$ of the total amount of land leasing area of city $i$ at year $t$ (or the control variable included in the city GDP growth model in equation (9)), and $Z_{i t}$ is a set of city characteristics that may affect its land expansion behaviors, including GDP per capita, the average wage in the city, the share of agricultural sector in GDP, total population, cultivated land per capita, the government deficit, the ratio of private workers to all workers, the ratio of FDI to GDP, and the degree of fiscal decentralization of the city. The first four variables capture the external needs of the city for land supply, and it is expected that economic development level, industrialization level, and population size all call for an expansion of a city's land supply (Deng et al., 2008). Since cities with more cultivated land per capita are usually in the less developed regions, this variable is expected to have a negative relationship with urban land expansion (Huang et al., 2015). The government deficit, defined as the difference between government expenditure and revenue as a percentage of GDP, reflects the internal needs of city governments for land expansion as a way to finance the gap. Finally, as emphasized by Huang et 
al. (2015), globalization, marketization, and decentralization in China's economy transition play an important role in urban land expansion in China. Following Huang et al. (2015), these three institutional factors are measured by the ratio of FDI to GDP, the ratio of private workers to all workers, and the ratio of fiscal expenditure per capita at city level to that at the provincial level, respectively.

Table 4 presents the results. The PMC fiscal reform dummy has a consistent positive and statistically significant coefficient, supporting our hypothesis of the incentive effect of the PMC fiscal reform on land expansion of the reformed cities for extra-budgetary revenues. The estimated coefficient of the reform dummy has a value around 0.14 across different specifications, implying that the reformed cities tend to expand land leasing at a rate 14 percent higher than the non-reformed cities.

As for the effects of control variables, we find that a higher level of economic development, globalization degree, and a larger population size lead to an expansion of land lease to sustain city development. Although the other control variables in general have the expected signs, they are statistically insignificant.

\subsection{Robustness Checks}

In order to test for the robustness of the basic results, we conduct sensitivity analysis along three dimensions. First, we re-estimate models (9) and (10) with a reduced sample size that excludes the capital city of each province. The rationale here is that the legal status of a capital city is not really comparable to other prefecture cities in the same province since they may differ dramatically in terms of administrative and fiscal status. In addition, since provincial governments physically locate in capital cities and since these cities are also generally endowed with the best economic and political resources for development, the change of vertical fiscal 
management models is anticipated to have smaller impacts on these cities and their belonging counties. Thus, we expect that the magnitude of the reform should increase when the capital cities are removed from the sample.

Second, instead of focusing on the effect of the introduction of the PMC fiscal reform directly, another way to capture this effect is to look at the intensity of the reform within the city. To do this, we replace the PMC fiscal reform dummy variable with a variable that is defined as the percentage of counties that have implemented the PMC fiscal reform in the total number of counties for a city in each year. A positive estimated coefficient of this variable would indicate that intensifying the reform leads to a larger policy effect.

Third, we take into account the potential endogeneity issue of the introduction of the PMC fiscal reform. ${ }^{20}$ A general concern in DID estimations is that, after conditioning on the observable characteristics, the changes of outcome variables in the treated and untreated cities would not be parallel in the absence of the PMC fiscal reform. We believe that this selection bias issue should not be a concern in our context because the direct targeting subjects of the reform are county governments and the selection criteria are the corresponding county characteristics, which in theory are not related to the performance of the city districts (e.g., the dependent variable). Nevertheless, this issue may still arise if the timing of the PMC fiscal reform is affected by the fiscal circumstances of the belonging counties of the city that is linked with the city's economic performance.

To account for such possibilities, we use an instrumental variable (IV) approach. We find three instruments for the introduction of the PMC fiscal reform in the city: a dummy variable indicating whether a province has officially announced its decision to implement the PMC fiscal

\footnotetext{
${ }^{20}$ Note that models (9) and (10) allow and control for the endogeneity of the introduction of the PMC reform caused by its correlation with city and year fixed effects.
} 
reform within its territory on a pilot basis (i.e., equal to 0 for years before the year that the provincial government announced its decision to implement the reform, and 1 for the years after the decision was announced and all the subsequent years); and two other dummies indicating whether a city contains at least one county that is defined by the central government as one of the major counties for producing grain or cotton, respectively. The use of the first instrument is based on the following argument: while only a province that has decided to implement the reform should have a particular county and its immediate responsible city selected as a reformed county/city, a particular county's economic performance and/or its land leasing behaviors should have no impact on whether its governing province will be selected by the central authority to implement the PMC fiscal reform. The use of the last two instruments is justified by the guiding principle of the Ministry of Finance that provincial governments should incorporate with priority those counties that produce a large amount of grain, oil plants and cotton, as previously noted. The underlying reason for this regulation is to make sure that this policy can be better extended to the most needed agricultural counties where fiscal stress has been most severe in the prereform period. Following this principle, counties recognized by the central government as major counties for producing grain or cotton are more likely to be chosen as reformed counties; nevertheless, the designated status of these major counties was generally determined by the central government in the early 1990s, years that are long before the implementation of the PMC fiscal reform. Therefore, we contend these three variables are reasonable instruments for the introduction of the PMC fiscal reform.

Tables 5 (city GDP growth) and 6 (city land lease) summarize these robustness results for the impact and the source of the PMC fiscal reform, respectively. To save space, we only present the estimation results for the baseline specification and the specification with a full set of control 
variables. In all the estimations presented in both tables, the PMC variable has a consistent positive and statistically significant coefficient, indicating that our previous results are quite robust across these alternative specifications. Columns (1) and (2) in Table 5 reveal a relative larger estimated coefficient of the PMC fiscal reform in comparison to the corresponding results in Table 3, which in turn is consistent with our prediction that dropping the capital cities from the sample is likely to increase the effect of the PMC fiscal reform. In columns (3) and (4) of Table 5, we replace the PMC fiscal reform dummy with our measure of the intensity of the reform, and we find a statistically significant coefficient for this variable, suggesting that, with the increase of county numbers in implementing the PMC fiscal reform within a city, the magnitude of its impact on city GDP growth increases. Columns (5) and (6) in Table 5 report the corresponding results from instrumental variable approaches that treat the PMC fiscal reform as endogenous. The F-test statistics from the first stage regression and the over-identifying restriction tests are noted at the bottom of Table 5. The F-statistics are large and statistically significant, indicating that the three instruments are good predictors of the PMC fiscal reform variable; the p-values of the Hansen J statistics suggest that we cannot reject the hypothesis of no correlation between the instruments and the error term in the regressions. The results in columns (5) and (6) are similar and comparable to those in the cases treating PMC fiscal reform as an exogenous variable. Overall, our previous finding on the positive growth effect of the PMC fiscal reform is not altered by taking the potential endogeneity of the PMC fiscal reform into account.

Similarly, Table 6 provides the corresponding robustness results for the impact of the PMC fiscal reform on the land leasing behavior of city governments, which serves as a potential channel through which the reform exerts its final impact on city GDP growth. These results are also largely the same as our earlier results. 


\section{Dynamic and Heterogeneous Effects of the PMC Fiscal Reform}

\subsection{Dynamic Effects of the PMC Fiscal Reform}

The standard regression DID models in equations (9) and (10) provide no insight on the dynamics of the impacts of the PMC fiscal reform; that is, how quickly do city governments expand land leasing and city GDP growth after the reform is implemented, and do these impacts accelerate, stabilize, or decline over time? To explore these dynamics, we modify the models to include leads and lags of the PMC fiscal reform (Autor, 2003; Bellou and Bhatt, 2013). Specifically, we re-estimate models (9) and (10), but in place of $P M C_{i t}$ we include a series of time dummies for the years leading up to a city's implementation of the PMC fiscal reform (i.e., indicator variables for $1,2,3,4$, and 5 years prior to the reform), the year of reform, and the years after reform (i.e., indicator variables for $1,2,3,4,5,6$, and 7 years after the reform). ${ }^{21}$ By focusing on the lags of the PMC fiscal reform, these new specifications allow us to examine the short and long run response of the cities to the reform. In addition, the leads variables (i.e., the year dummies leading up to the reform) provide us an opportunity to check whether there is any evidence of pre-existing trends, which in turn serves as an alternative way to verify whether our main results suffer from selection bias. ${ }^{22}$

The results of the base specifications augmented with the leads and lags of the PMC fiscal reform are presented in Tables 7 and 8 for the growth equation and land expansion equation, respectively. Looking at the year dummies leading up to the PMC fiscal reform, we observe estimates that are not statistically different from zero in almost all estimations in both

\footnotetext{
${ }^{21}$ Note that the covered period for our analysis is 1999-2011, and the first year for the implementation of the PMC reform is 2004 (excepting the Zhejiang province).

${ }^{22}$ The identifying assumption for the DID model is that the control cities act as a valid comparison group for the treated cities. If this assumption does not hold, then the estimated effects of the reform may simply reflect a continuation of the trend that already exists prior to the reform.
} 
tables, showing little evidence of an anticipatory response of the cities about to implement a reform. In the year of the reform, the estimates are positive and statistically insignificant in the growth equation, after which they remain positive but become strongly significant in the subsequent years.

Turning to the year of the reform and its subsequent year dummies in the land expansion equation, all the estimates are positive and statistically significant. The results reveal two noteworthy findings. First, the PMC fiscal reform has an immediate impact on the cities' fiscal budgets and so an immediate impact on the land leasing decision of city governments, which in turn takes a one to two year lag to transform the impact into city GDP growth. Second, the dynamic results indicate a strengthening effect of the PMC fiscal reform over time after the reform is introduced, roughly a tripling of the effect over a 7 year implementation of the reform. $^{23}$ This result may reflect the fact that it takes time for city governments to adjust fully to the changes in their fiscal circumstances. Also, the expansion of land leasing itself may take up to several years to complete, depending on the forms of leasing (e.g., auction or negotiation). ${ }^{24}$

\subsection{Heterogeneous Effects of the PMC Fiscal Reform}

The starting point of our analysis is based on the general observation that, by cutting off the fiscal relationship between city and county governments, the PMC fiscal reform will result in city governments losing revenues and also expanding their land leasing policy. The validity of this argument depends crucially on the fiscal circumstances of the city before the reform, especially the relative fiscal circumstances of the city districts and its belonging counties. For cities that are relatively rich in comparison to their belonging counties, it is reasonable to expect

\footnotetext{
${ }^{23}$ The strengthening effect of the PMC reform is obtained basing on our analyzed time frame, it would be interesting to see if this strengthening effect remains valid when more post-reform periods become available and check further the role played by land leasing behaviors of city governments.

${ }^{24}$ Currently, local governments in China may lease land to commercial users mainly through four mechanisms, including one-to-one negotiation, auction, public tender, and listing of quotation (Tao et al., 2010).
} 
that the "grabbing" hand of these city governments before the reform would be less severe than their counterpart cities that are relatively poor compared to their belonging counties (i.e., a relatively smaller $G$ in the theoretical model of section 3). Thus, the introduction of the PMC fiscal reform should have a less salient effect on the richer group of cities.

To capture this potentially heterogeneous effect and also to serve as a way of providing further evidence for our main hypothesis, we re-estimate the city GDP growth model of equation (9) and the land expansion model of equation (10) by adding two more variables: the relative rich extent of the city, defined as the ratio of the GDP of city districts to the GDP of the entire city (i.e., combination of city districts and counties); and an interaction term between the introduction of the PMC fiscal reform and the relative rich extent of the city. We are particularly interested in the estimated coefficient of the interaction term, as a negative value would provide evidence that the quantitative impacts of the PMC fiscal reform become smaller with the increase of the relative income of the cities.

Tables 9 and 10 report the new estimation results for the city GDP growth equation and the land expansion equation, respectively. Across all estimations in both tables, the estimated coefficients of the PMC fiscal reform dummy remain positive and statistically significant. Also, the coefficients of the interaction term are consistently negative, confirming the existence of a heterogeneous effect of the reform; that is, the positive effects of the reform on city GDP growth and on land expansion become weaker when the cities are relatively richer comparing to their belonging counties. Although the estimated coefficients of the interaction term are in general statistically insignificant in Table 9, the joint test for the PMC fiscal reform dummy and the interaction term is generally significant at the 5 percent level. Finally, the effects of the remaining control variables in both equations are largely unchanged. 


\section{$\underline{\text { 7. Conclusions }}$}

We find that the PMC fiscal reform has increased economic growth of the reformed cities, on average at the rate around 1 percentage point. This is somewhat counter to the anecdotal criticism on the PMC fiscal reform, which worries about the potential detrimental effects of the reform on city GDP growth. Even so, we believe that one must be careful with the interpretation of this result, as our further analysis indicates that city GDP growth is partially gained at the cost of expanding land supply. ${ }^{25}$ Reformed cities tend to expand land leasing at a speed that is 14 percent higher than the non-reformed cities.

Given that the aggressive urban land expansion over the past decades in China has led to a series of social problem including large scale losses of farmland, rapidly rising house prices, and increased social disruptions, the effect of the PMC fiscal reform on the land grabbing behaviors of city governments requires serious evaluation by the central authority. Indeed, from a policy perspective, if the continued expansion of urban land use and so the continued loss of farmland is deemed undesirable by the national authorities, then there will be a need for taking the interests of prefecture city level governments into consideration when implementing further PMC-type reforms. Rethinking the assignment for revenue sources to match expenditure responsibilities for different levels of governments is critical for the success of the PMC fiscal reform.

\footnotetext{
${ }^{25}$ Recall that according to our empirical results, there appears to exist other channels (besides land expansion) through which the PMC reform exerts a positive impact on city GDP growth. One possible such channel may be due to the fact that the PMC reform brings more fiscal resources and authorities to the county governments and so promotes county economic development, which in turn generates a positive spillover effects on the GDP growth of city districts. In this case, even if land lease gradually and eventually becomes less important in promoting urban growth in China, we may still expect a positive effect of the PMC reform on city GDP growth.
} 
In all, flattening the pyramid of local governance is a difficult task, and systematic

evaluation of the current ongoing PMC fiscal reform requires considering all of its possible impacts on all levels of governments. Further reforms should be built on the knowledge - both positive and negative - that we hope to learn from this research.

\section{References}

Anderson, G., \& Ge, Y. (2004). Do Economic Reforms Accelerate Urban Growth? The Case of China. Urban Studies, 41(11), 2197-2210.

Anglin, P. M., Dale-Johnson, D., Gao, Y., \& Zhu, G. (2014). Patterns of Growth in Chinese Cities: Implications of the Land Lease. Journal of Urban Economics, 83(0), 87-107.

Au, C.-C., \& Henderson, J. V. (2006). Are Chinese Cities Too Small? The Review of Economic Studies, 73(3), 549-576.

Autor, D. H. (2003). Outsourcing at Will: The Contribution of Unjust Dismissal Doctrine to the Growth of Employment Outsourcing. Journal of Labor Economics, 21(1), 1-42.

Bellou, A., \& Bhatt, R. (2013). Reducing Underage Alcohol and Tobacco Use: Evidence from the Introduction of Vertical Identification Cards. Journal of Health Economics, 32(2), 353-366.

Berthélemy, J.-C., \& Démurger, S. (2000). Foreign Direct Investment and Economic Growth: Theory and Application to China. Review of Development Economics, 4(2), 140-155.

Bertrand, M., Duflo, E., \& Mullainathan, S. (2004). How Much Should We Trust Differences-InDifferences Estimates? The Quarterly Journal of Economics, 119(1), 249-275.

Cai, G., \& Huang, L. (2010). A Study on the Influential Factors of the Government's Hierarch Reform and on their Economic Performance. Management World (In Chinese), 8, 73-83.

Chen, B., \& Feng, Y. (2000). Determinants of Economic Growth in China: Private Enterprise, Education, and Openness. China Economic Review, 11(1), 1-15.

Ciccone, A., \& Hall, R. E. (1996). Productivity and the Density of Economic Activity. The American Economic Review, 86(1), 54-70.

Deng, X., Huang, J., Rozelle, S., \& Uchida, E. (2008). Growth, Population and Industrialization, and Urban Land Expansion of China. Journal of Urban Economics, 63(1), 96-115.

Ding, C., \& Lichtenberg, E. (2011). Land and Urban Economic Growth in China. Journal of Regional Science, 51(2), 299-317.

Galiani, S., Gertler, P., \& Schargrodsky, E. (2005). Water for Life: The Impact of the Privatization of Water Services on Child Mortality. Journal of Political Economy, 113(1), 83-120.

Gao, T. (2004). Regional Industrial Growth: Evidence from Chinese Industries. Regional Science and Urban Economics, 34(1), 101-124.

Gordon, R. H., and W. Li. Provincial and Local Governments in China: Fiscal Institutions and Government Behavior. National Bureau of Economic Research Working Paper Series No. 16694, 2011. 
He, C. (2002). Information Costs, Agglomeration Economies and the Location of Foreign Direct Investment in China. Regional Studies, 36(9), 1029-1036.

He, C., Huang, Z., \&Wang, R. (2014). Land Use Change and Economic Growth in Urban China: A Structural Equation Analysis. Urban Studies, 51(3), 2880-2898.

He, C., \& Pan, F. (2010). Economic Transition, Dynamic Externalities and City-industry Growth in China. Urban Studies, 47(1), 121-144.

Huang, Z., Wei, Y. D., He, C., \& Li, H. (2015). Urban Land Expansion under Economic Transition in China: A Multi-level Modeling Analysis. Habitat International, 47, 69-82.

Jin, H., Qian, Y., \& Weingast, B. R. (2005). Regional Decentralization and Fiscal Incentives: Federalism, Chinese Style. Journal of Public Economics, 89(9-10), 1719-1742.

Lichtenberg, E., \& Ding, C. (2009). Local Officials as Land Developers: Urban Spatial Expansion in China. Journal of Urban Economics, 66(1), 57-64.

Lin, J. Y., \& Liu, Z. (2000). Fiscal Decentralization and Economic Growth in China. Economic Development and Cultural Change, 49(1), 1-21.

Lin, S., \& Song, S. (2002). Urban Economic Growth in China: Theory and Evidence. Urban Studies, 39(12), 2251-2266.

Liu, J., Ma, L., \& Wu, J.-n. (2011). Province-Managing-County Reform and Mitigation of Fiscal Deficiencies of County Governments in China: An Empirical Analysis of Panel Data from Six Provinces. Journal of Public Management (In Chinese), 8(3), 33-43.

Liu, J., Wu, J., \& Wu, J. (2012). The Influence of the Province-Managing-County Reform on Public Goods Provision of Counties: An Empirical Analysis of Panel Data from 136 Counties and Cities in Hebei Province. Comparative Economic \& Social Systems (In Chinese), 159(1), 36-45.

Liu, M., Tao, R., Yuan, F., \& Cao, G. (2008). Instrumental Land Use Investment-driven Growth in China. Journal of the Asia Pacific Economy, 13(3), 313-331.

Liu, Y., \& Martinez-Vazquez, J. (2014). Interjurisdictional Tax Competition in China. Journal of Regional Science, 54(4),

Liu, Y., Martinez-Vazquez, J., \& Qiao, B. (2014). Falling Short: Intergovernmental Transfers in China. Public Finance and Management, 14(4), 374-398.

Luo, R., Zhang, L., Huang, J., \& Rozelle, S. (2007). Elections, Fiscal Reform and Public Goods Provision in Rural China. Journal of Comparative Economics, 35(3), 583-611.

Martinez-Vazquez, J., Qiao, B., Wang, S., \& Zou, H.-f. (2014). An Essay on Public Finance in China. Annals of Economics and Finance, 15(1), 413-519.

Martinez-Vazquez, J., Qiao, B., \& Zhang, L. (2008). The Role of Provincial Policies in Fiscal Equalization Outcomes in China. China Review, 8(2), 135-167.

Nitikin, D., Shen, C., Wang, Q., \& Zou, H.-f. (2012). Land Taxation in China: Assessment of Prospects for Politically and Economically Sustainable Reform. Annals of Economics and Finance, 13(2), 489-528.

Peterson, G. E. (2006). Land Leasing And Land Sale As An Infrastructure-Financing Option: The World Bank.

Phillips, K. L., \& Shen, K. (2005). What Effect Does the Size of the State-owned Sector Have on Regional Growth in China? Journal of Asian Economics, 15(6), 1079-1102.

Qiao, B., Martinez-Vazquez, J., \& Xu, Y. (2008). The Tradeoff between Growth and Equity in Decentralization Policy: China's Experience. Journal of Development Economics, 86(1), 112-128. 
Tao, R., Su, F., Liu, M., \& Cao, G. (2010). Land Leasing and Local Public Finance in China's Regional Development: Evidence from Prefecture-level Cities. Urban Studies, 47(10), 2217-2236.

Wang, W., Zheng, X., \& Zhao, Z. (2011). Fiscal Reform and Public Education Spending: A Quasi-natural Experiment of Fiscal Decentralization in China. Publius: The Journal of Federalism, 42(2), 334-356.

World Bank. (2002). China - National Development and Sub-national Finance: A Review of Provincial Expenditures Public Expenditure Review (PER). Washington, DC: World Bank.

Xu, C. (2011). The Fundamental Institutions of China's Reforms and Development. Journal of Economic Literature, 49(4), 1076-1151.

Zhang, K. H. (2001). How Does Foreign Direct Investment Affect Economic Growth in China? Economics of Transition, 9(3), 679-693.

Zhang, T., \& Zou, H.-f. (1998). Fiscal Decentralization, Public Spending, and Economic Growth in China. Journal of Public Economics, 67(2), 221-240.

Zheng, F. (2009). "Province-Managing-County" Reform Cannot Solve Everything. People's Tribune, 18, 5-5.

Zheng, X., Wang, H., \& Zhao, Y. (2011). Does "Province-Managing-County" Reform Promote Economic Growth? A Difference-in-Difference Approach. Management World (In Chinese), 8, 34-65. 
Table 1.A. Description and Sources of Variables

\begin{tabular}{|c|c|c|}
\hline Variable & Definition & Source \\
\hline GDP growth rate & Annual GDP growth rate & $\begin{array}{l}\text { China City Statistical } \\
\text { Yearbook }\end{array}$ \\
\hline Total land lease & Total area of land lease in hectares $(\log )$ & $\begin{array}{l}\text { China Land and } \\
\text { Resources Yearbook }\end{array}$ \\
\hline PMC fiscal reform & $\begin{array}{l}\text { Dummy variable for the implementation of the } \\
\text { PMC fiscal reform }\end{array}$ & $\begin{array}{l}\text { Official documents } \\
\text { released by provincial } \\
\text { governments }\end{array}$ \\
\hline PMC intensity & $\begin{array}{l}\text { Percentage of counties that have implemented the } \\
\text { PMC fiscal reform in total number of counties for a } \\
\text { city }\end{array}$ & $\begin{array}{l}\text { Official documents } \\
\text { released by provincial } \\
\text { governments }\end{array}$ \\
\hline Capital investment & $\begin{array}{l}\text { Ratio of total amount of fixed capital investment } \\
\text { to GDP }\end{array}$ & $\begin{array}{l}\text { China City Statistical } \\
\text { Yearbook }\end{array}$ \\
\hline Population growth & Annual population growth rate & $\begin{array}{l}\text { China City Statistical } \\
\text { Yearbook }\end{array}$ \\
\hline FDI/GDP & Ratio of FDI to GDP & $\begin{array}{l}\text { China City Statistical } \\
\text { Yearbook }\end{array}$ \\
\hline $\begin{array}{l}\text { Agricultural } \\
\text { sector/GDP }\end{array}$ & Ratio of the agricultural sector in total GDP & $\begin{array}{l}\text { China City Statistical } \\
\text { Yearbook }\end{array}$ \\
\hline $\begin{array}{l}\text { Economic } \\
\text { agglomeration }\end{array}$ & Urban population density $(\log )$ & $\begin{array}{l}\text { China City Statistical } \\
\text { Yearbook }\end{array}$ \\
\hline Inflation & Consumer price index at provincial level & $\begin{array}{l}\text { China City Statistical } \\
\text { Yearbook }\end{array}$ \\
\hline $\begin{array}{l}\text { Government } \\
\text { expenditures/GDP }\end{array}$ & Ratio of government expenditure to GDP & $\begin{array}{l}\text { China City Statistical } \\
\text { Yearbook }\end{array}$ \\
\hline Rich level of the city & $\begin{array}{l}\text { Ratio of the GDP of city districts to the GDP } \\
\text { of the entire city }\end{array}$ & $\begin{array}{l}\text { China City Statistical } \\
\text { Yearbook }\end{array}$ \\
\hline GDP per capita & GDP per capita $(\log )$ & $\begin{array}{l}\text { China City Statistical } \\
\text { Yearbook }\end{array}$ \\
\hline Total population & Total population $(\log )$ & $\begin{array}{l}\text { China City Statistical } \\
\text { Yearbook }\end{array}$ \\
\hline $\begin{array}{l}\text { Government } \\
\text { deficit/GDP }\end{array}$ & $\begin{array}{l}\text { The difference between government expenditure and } \\
\text { revenue as a percentage of GDP }\end{array}$ & $\begin{array}{l}\text { China City Statistical } \\
\text { Yearbook }\end{array}$ \\
\hline $\begin{array}{l}\text { Cultivation land per } \\
\text { capita }(\log )\end{array}$ & Cultivation land per capita $(\log )$ & $\begin{array}{l}\text { China City Statistical } \\
\text { Yearbook }\end{array}$ \\
\hline $\begin{array}{l}\text { Average wage per } \\
\text { capita }(\log )\end{array}$ & Average wage per capita of the city $(\log )$ & $\begin{array}{l}\text { China City Statistical } \\
\text { Yearbook }\end{array}$ \\
\hline Marketization & Ratio of private workers to whole workers & $\begin{array}{l}\text { China City Statistical } \\
\text { Yearbook }\end{array}$ \\
\hline $\begin{array}{l}\text { Fiscal } \\
\text { decentralization }\end{array}$ & $\begin{array}{l}\text { Ratio of fiscal expenditure per capita at city level to } \\
\text { that at the provincial level }\end{array}$ & $\begin{array}{l}\text { China City Statistical } \\
\text { Yearbook }\end{array}$ \\
\hline
\end{tabular}


Table 1.B. Summary Statistics

\begin{tabular}{|c|c|c|c|c|c|c|c|c|c|}
\hline \multirow[b]{2}{*}{ Variables } & \multicolumn{3}{|c|}{ Full Sample } & \multicolumn{3}{|c|}{ Reformed Cities } & \multicolumn{3}{|c|}{ Non-reformed Cities } \\
\hline & Obs. & Mean & $\begin{array}{l}\text { Std. } \\
\text { Dev. }\end{array}$ & Obs. & Mean & $\begin{array}{l}\text { Std. } \\
\text { Dev. }\end{array}$ & Obs. & Mean & Std. Dev. \\
\hline GDP growth rate $(\%)$ & 3289 & 13.01 & 4.92 & 2527 & 12.86 & 4.69 & 762 & 13.50 & 5.60 \\
\hline Total land lease (log) & 3232 & 5.49 & 1.36 & 2497 & 5.54 & 1.36 & 735 & 5.29 & 1.34 \\
\hline PMC fiscal reform & 3237 & 0.32 & 0.47 & 2527 & 0.42 & 0.49 & 710 & - & - \\
\hline PMC intensity & 3146 & 0.25 & 0.40 & 2527 & 0.31 & 0.43 & 619 & - & - \\
\hline Capital investment & 3251 & 0.51 & 0.25 & 2500 & 0.52 & 0.24 & 751 & 0.50 & 0.26 \\
\hline FDI/GDP & 3142 & 0.03 & 0.05 & 2436 & 0.03 & 0.04 & 706 & 0.04 & 0.08 \\
\hline $\begin{array}{l}\text { Agricultural } \\
\text { sector/GDP }\end{array}$ & 3189 & 8.63 & 8.52 & 2457 & 9.18 & 8.81 & 732 & 6.78 & 7.18 \\
\hline $\begin{array}{l}\text { Economic } \\
\text { agglomeration }\end{array}$ & 3223 & -3.20 & 1.24 & 2479 & -3.23 & 1.24 & 744 & -3.08 & 1.22 \\
\hline Population growth (\%) & 3269 & 5.56 & 3.76 & 2516 & 5.56 & 3.57 & 753 & 5.57 & 4.34 \\
\hline Inflation $(\%)$ & 3289 & 102.19 & 2.52 & 2527 & 102.22 & 2.53 & 762 & 102.10 & 2.51 \\
\hline $\begin{array}{l}\text { Government } \\
\text { expenditures/GDP }\end{array}$ & 3252 & 0.12 & 0.06 & 2501 & 0.12 & 0.06 & 751 & 0.12 & 0.07 \\
\hline Rich level of the city & 3242 & 0.44 & 0.23 & 2497 & 0.39 & 0.19 & 745 & 0.61 & 0.28 \\
\hline GDP per capita (log) & 3159 & 9.86 & 0.80 & 2490 & 9.81 & 0.79 & 669 & 10.04 & 0.79 \\
\hline Secondary sector/GDP & 3189 & 50.80 & 12.98 & 2457 & 50.02 & 12.57 & 732 & 53.42 & 13.95 \\
\hline Total population (log) & 3172 & 4.37 & 0.59 & 2501 & 4.41 & 0.58 & 671 & 4.23 & 0.62 \\
\hline $\begin{array}{l}\text { Government } \\
\text { deficit/GDP }\end{array}$ & 3247 & 0.06 & 0.06 & 2499 & 0.06 & 0.06 & 748 & 0.05 & 0.06 \\
\hline $\begin{array}{l}\text { Cultivation land per } \\
\text { capita }(\log )\end{array}$ & 3243 & 6.50 & 0.71 & 2512 & 6.52 & 0.63 & 731 & 6.42 & 0.92 \\
\hline $\begin{array}{l}\text { Average wage per } \\
\text { capita (log) }\end{array}$ & 3254 & 8.31 & 0.50 & 2510 & 8.29 & 0.49 & 744 & 8.39 & 0.53 \\
\hline Marketization & 3252 & 0.37 & 0.15 & 2507 & 0.36 & 0.14 & 745 & 0.39 & 0.17 \\
\hline Fiscal decentralization & 3171 & 1.25 & 0.71 & 2500 & 1.28 & 0.72 & 671 & 1.16 & 0.68 \\
\hline
\end{tabular}

Note: Reformed cities refer to those cities that implemented the PMC fiscal reform by the end of 2011; non-reformed cities are those cities that have not implemented the reform throughout the whole period in our sample. 
Table 2. Implementation of the PMC Fiscal Reform across Provinces

\begin{tabular}{|c|c|c|c|c|c|c|c|}
\hline \multirow[b]{2}{*}{ Province } & \multirow[b]{2}{*}{ Total Cities } & \multicolumn{2}{|c|}{ Reformed Cities } & \multirow[b]{2}{*}{ Province } & \multirow[b]{2}{*}{ Total Cities } & \multicolumn{2}{|c|}{ Reformed Cities } \\
\hline & & 2004 & 2011 & & & 2004 & 2011 \\
\hline Anhui & 17 & 12 & 12 & Jilin & 9 & 0 & 9 \\
\hline Fujian & 9 & 8 & 8 & Liaoning & 14 & 0 & 1 \\
\hline Gansu & 14 & 0 & 13 & Inner Mongolia & 12 & 0 & 0 \\
\hline Guangdong & 21 & 0 & 4 & Ningxia & 5 & 0 & 0 \\
\hline Guangxi & 14 & 0 & 14 & Qinghai & 8 & 0 & 2 \\
\hline Guizhou & 9 & 0 & 3 & Shaanxi & 10 & 0 & 10 \\
\hline Hainan & 2 & 0 & 0 & Shandong & 17 & 0 & 14 \\
\hline Hebei & 11 & 0 & 11 & Shanxi & 11 & 0 & 10 \\
\hline Heilongjiang & 13 & 0 & 13 & Sichuan & 21 & 0 & 16 \\
\hline Henan & 17 & 4 & 15 & Tibet & 7 & 0 & 0 \\
\hline Hubei & 13 & 10 & 10 & Xinjiang & 14 & 0 & 0 \\
\hline Hunan & 14 & 0 & 13 & Yunnan & 16 & 0 & 3 \\
\hline Jiangsu & 13 & 0 & 13 & Zhejiang & 11 & 11 & 11 \\
\hline Jiangxi & 11 & 0 & 11 & & & & \\
\hline
\end{tabular}


Table 3. Effect of the PMC Fiscal Reform on City GDP Growth

\begin{tabular}{|c|c|c|c|c|c|}
\hline & (1) & (2) & (3) & (4) & (5) \\
\hline \multirow[t]{2}{*}{ PMC fiscal reform } & $0.991 * * *$ & $0.839 * *$ & $0.796 * *$ & $0.710 * *$ & $0.705 * *$ \\
\hline & $(3.022)$ & $(2.470)$ & $(2.334)$ & $(2.121)$ & $(2.045)$ \\
\hline \multirow[t]{2}{*}{ Total land lease } & & & $0.438 * * *$ & $0.378 * *$ & $0.372 * *$ \\
\hline & & & $(2.760)$ & $(2.402)$ & $(2.260)$ \\
\hline \multirow[t]{2}{*}{ Capital investment } & & & & $2.347 * * *$ & $2.151 * * *$ \\
\hline & & & & $(3.516)$ & $(3.068)$ \\
\hline \multirow[t]{2}{*}{ FDI/GDP } & & & & & $9.312 * * *$ \\
\hline & & & & & $(4.280)$ \\
\hline \multirow[t]{2}{*}{ GDP per capita } & & $-2.509 * * *$ & $-2.787 * * *$ & $-2.530 * * *$ & $-2.400 * * *$ \\
\hline & & $(-3.226)$ & $(-3.491)$ & $(-3.117)$ & $(-2.889)$ \\
\hline \multirow[t]{2}{*}{ Agricultural sector/GDP } & & $-0.129 * * *$ & $-0.124 * * *$ & $-0.109 * * *$ & $-0.113 * * *$ \\
\hline & & $(-2.975)$ & $(-2.906)$ & $(-2.619)$ & $(-2.646)$ \\
\hline \multirow[t]{2}{*}{ Economic agglomeration } & & $0.793 * *$ & $0.857 * *$ & $0.805 * *$ & $0.722 * *$ \\
\hline & & $(2.435)$ & $(2.592)$ & $(2.415)$ & $(2.152)$ \\
\hline \multirow[t]{2}{*}{ Population growth } & & -0.034 & -0.033 & -0.039 & -0.037 \\
\hline & & $(-0.976)$ & $(-0.906)$ & $(-1.101)$ & $(-0.985)$ \\
\hline \multirow[t]{2}{*}{ Inflation } & & $-0.287 * *$ & $-0.276^{* *}$ & $-0.252 * *$ & $-0.252 * *$ \\
\hline & & $(-2.566)$ & $(-2.457)$ & $(-2.257)$ & $(-2.099)$ \\
\hline \multirow[t]{2}{*}{ Government expenditure/GDP } & & $11.639 * * *$ & $11.082 * * *$ & $9.080 * * *$ & $8.908 * * *$ \\
\hline & & $(5.055)$ & $(4.898)$ & $(4.009)$ & $(3.414)$ \\
\hline City FE & Yes & Yes & Yes & Yes & Yes \\
\hline Year FE & Yes & Yes & Yes & Yes & Yes \\
\hline Observations & 3,237 & 3,030 & 2,983 & 2,979 & 2,889 \\
\hline R-squared & 0.249 & 0.285 & 0.287 & 0.292 & 0.299 \\
\hline Number of cities & 263 & 261 & 261 & 261 & 261 \\
\hline
\end{tabular}

Note: The dependent variable is the city GDP growth rate. Huber-White robust t-statistics are in parentheses, where $* * * \mathrm{p}<0.01, * * \mathrm{p}<0.05, * \mathrm{p}<0.1$. 
Table 4. Effect of the PMC Fiscal Reform on City Land Lease

\begin{tabular}{|c|c|c|c|c|c|}
\hline & $(1)$ & $(2)$ & $(3)$ & $(4)$ & $(5)$ \\
\hline PMC fiscal reform & $\begin{array}{c}0.151 * * \\
(2.521)\end{array}$ & $\begin{array}{c}0.140 * * \\
(2.549)\end{array}$ & $\begin{array}{c}0.143 * * * \\
(2.639)\end{array}$ & $\begin{array}{c}0.137 * * * \\
(2.631)\end{array}$ & $\begin{array}{c}0.137 * * * \\
(2.618)\end{array}$ \\
\hline GDP per capita & & $\begin{array}{c}0.505^{* * * *} \\
(3.385)\end{array}$ & $\begin{array}{c}0.528 * * * \\
(3.474)\end{array}$ & $\begin{array}{c}0.519 * * * \\
(3.437)\end{array}$ & $\begin{array}{c}0.479 * * * \\
(2.994)\end{array}$ \\
\hline Agricultural sector/GDP & & $\begin{array}{c}-0.001 \\
(-0.142)\end{array}$ & $\begin{array}{c}-0.003 \\
(-0.450)\end{array}$ & $\begin{array}{c}-0.003 \\
(-0.405)\end{array}$ & $\begin{array}{c}-0.005 \\
(-0.725)\end{array}$ \\
\hline Total population & & & $\begin{array}{l}0.267^{*} \\
(1.795)\end{array}$ & $\begin{array}{l}0.269^{*} \\
(1.796)\end{array}$ & $\begin{array}{c}0.393 * * \\
(2.517)\end{array}$ \\
\hline Cultivation land per capita & & & $\begin{array}{c}-0.076 \\
(-1.458)\end{array}$ & $\begin{array}{c}-0.068 \\
(-1.342)\end{array}$ & $\begin{array}{c}-0.080 \\
(-1.570)\end{array}$ \\
\hline Average wage per capita & & & & $\begin{array}{c}0.256 * * \\
(2.566)\end{array}$ & $\begin{array}{c}0.233 * * \\
(2.446)\end{array}$ \\
\hline Government deficit/GDP & & & & $\begin{array}{c}0.442 \\
(0.751)\end{array}$ & $\begin{array}{c}0.159 \\
(0.196)\end{array}$ \\
\hline Marketization & & & & & $\begin{array}{c}-0.162 \\
(-0.783)\end{array}$ \\
\hline FDI/GDP & & & & & $\begin{array}{c}1.003 * * \\
(2.057)\end{array}$ \\
\hline Fiscal decentralization & & & & & $\begin{array}{c}0.056 \\
(0.878)\end{array}$ \\
\hline Observations & 3,185 & 3,022 & 3,014 & 3,007 & 2,909 \\
\hline R-squared & 0.598 & 0.616 & 0.616 & 0.618 & 0.624 \\
\hline Number of cities & 263 & 261 & 260 & 260 & 260 \\
\hline
\end{tabular}

Note: The dependent variable is the log of the total land lease of the city. Huber-White robust t-statistics are in parentheses, where $* * * \mathrm{p}<0.01, * * \mathrm{p}<0.05, * \mathrm{p}<0.1$. 
Table 5. Robustness Tests of PMC Fiscal Reform on City GDP Growth

\begin{tabular}{|c|c|c|c|c|c|c|}
\hline & \multicolumn{2}{|c|}{ Reduced subsample } & \multicolumn{2}{|c|}{ PMC intensity } & \multicolumn{2}{|c|}{ IV estimation } \\
\hline & $(1)$ & $(2)$ & (3) & (4) & $(5)$ & $(6)$ \\
\hline PMC fiscal reform & $\begin{array}{c}1.134 * * * \\
(3.339)\end{array}$ & $\begin{array}{c}0.826^{* * *} \\
(2.302)\end{array}$ & & & $\begin{array}{c}1.026^{* * * *} \\
(3.174)\end{array}$ & $\begin{array}{c}0.824 * * \\
(2.404)\end{array}$ \\
\hline PMC intensity & & & $\begin{array}{c}1.976^{* * *} \\
(5.097)\end{array}$ & $\begin{array}{c}1.730 * * * \\
(4.530)\end{array}$ & & \\
\hline Total land lease & & $\begin{array}{l}0.338^{*} \\
(1.962)\end{array}$ & & $\begin{array}{c}0.326 * * \\
(1.978)\end{array}$ & & $\begin{array}{c}0.370 * * \\
(2.486)\end{array}$ \\
\hline Capital investment & & $\begin{array}{c}2.150 * * * \\
(2.926)\end{array}$ & & $\begin{array}{c}1.800 * * * \\
(2.672)\end{array}$ & & $\begin{array}{c}2.139 * * * \\
(3.405)\end{array}$ \\
\hline FDI/GDP & & $\begin{array}{c}9.069 * * * \\
(4.046)\end{array}$ & & $\begin{array}{c}9.231^{* * *} * \\
(4.194)\end{array}$ & & $\begin{array}{c}9.294 * * * \\
(5.003)\end{array}$ \\
\hline GDP per capita & & $\begin{array}{c}-2.269 * * \\
(-2.579)\end{array}$ & & $\begin{array}{c}-2.398 * * * \\
(-2.885)\end{array}$ & & $\begin{array}{c}-2.389 * * * \\
(-3.493)\end{array}$ \\
\hline Agricultural sector/GDP & & $\begin{array}{c}-0.107 * * \\
(-2.506)\end{array}$ & & $\begin{array}{c}-0.116 * * * \\
(-2.775)\end{array}$ & & $\begin{array}{c}-0.114 * * * \\
(-3.134)\end{array}$ \\
\hline Economic agglomeration & & $\begin{array}{c}0.790 * * \\
(2.296)\end{array}$ & & $\begin{array}{c}0.700^{* *} \\
(2.174)\end{array}$ & & $\begin{array}{c}0.713 * * * \\
(2.648)\end{array}$ \\
\hline Population growth & & $\begin{array}{c}-0.028 \\
(-0.714)\end{array}$ & & $\begin{array}{c}-0.025 \\
(-0.654)\end{array}$ & & $\begin{array}{c}-0.037 \\
(-1.051)\end{array}$ \\
\hline Inflation & & $\begin{array}{c}-0.278 * * \\
(-2.123)\end{array}$ & & $\begin{array}{c}-0.272 * * \\
(-2.271)\end{array}$ & & $\begin{array}{c}-0.254 * * \\
(-2.173)\end{array}$ \\
\hline Government expenditure/GDP & & $\begin{array}{c}9.368 * * * \\
(3.450)\end{array}$ & & $\begin{array}{c}8.322 * * * \\
(3.150)\end{array}$ & & $\begin{array}{c}8.859 * * * \\
(3.427)\end{array}$ \\
\hline Observations & 3,028 & 2,719 & 3,146 & 2,842 & 3,237 & 2,886 \\
\hline R-squared & 0.249 & 0.299 & 0.249 & 0.299 & 0.249 & 0.299 \\
\hline Number of cities & 246 & 246 & 256 & 254 & 263 & 258 \\
\hline Cragg-Donald F Statistic & & & & & 2075 & 1813 \\
\hline Hansen J statistic (p-value) & & & & & 0.577 & 0.275 \\
\hline
\end{tabular}

Note: The dependent variable is the city GDP growth rate. Huber-White robust t-statistics are in parentheses, where $* * * \mathrm{p}<0.01, * * \mathrm{p}<0.05, * \mathrm{p}<0.1$. The reduced sample does not include the capital city of each province; the PMC intensity represents the percentage of counties that have implemented the PMC fiscal reform in the total number of counties for a city; the instruments in the IV estimations include a dummy indicating whether a province has officially announced its decision to implement the PMC fiscal reform within its territory and two other dummies indicating whether a city contains at least one county that is defined by the central government as one of the major counties for producing grain or cotton, respectively. 
Table 6. Robustness Tests of PMC Fiscal Reform on City Land Lease

\begin{tabular}{|c|c|c|c|c|c|c|}
\hline & \multicolumn{2}{|c|}{ Reduced subsample } & \multicolumn{2}{|c|}{ PMC intensity } & \multicolumn{2}{|c|}{ IV estimation } \\
\hline & (1) & (2) & (3) & $(4)$ & $(5)$ & $(6)$ \\
\hline PMC fiscal reform & $\begin{array}{c}0.162 * * * \\
(2.636)\end{array}$ & $\begin{array}{c}0.157 * * * \\
(2.928)\end{array}$ & & & $\begin{array}{c}0.228 * * * \\
(4.345)\end{array}$ & $\begin{array}{c}0.213 * * * \\
(4.041)\end{array}$ \\
\hline PMC intensity & & & $\begin{array}{c}0.198 * * * \\
(2.890)\end{array}$ & $\begin{array}{c}0.232 * * * \\
(3.537)\end{array}$ & & \\
\hline GDP per capita & & $\begin{array}{c}0.501 * * * \\
(2.972)\end{array}$ & & $\begin{array}{c}0.478 * * * \\
(2.932)\end{array}$ & & $\begin{array}{c}0.491 * * * \\
(3.608)\end{array}$ \\
\hline Agricultural sector/GDP & & $\begin{array}{c}-0.003 \\
(-0.441)\end{array}$ & & $\begin{array}{c}-0.005 \\
(-0.692)\end{array}$ & & $\begin{array}{c}-0.002 \\
(-0.315)\end{array}$ \\
\hline Total population & & $\begin{array}{c}0.470 * * * \\
(3.227)\end{array}$ & & $\begin{array}{c}0.384 * * \\
(2.475)\end{array}$ & & $\begin{array}{c}0.431 * * * \\
(3.349)\end{array}$ \\
\hline Cultivation land per capita & & $\begin{array}{c}-0.079 \\
(-1.547)\end{array}$ & & $\begin{array}{l}-0.090^{*} \\
(-1.762)\end{array}$ & & $\begin{array}{l}-0.083 * \\
(-1.679)\end{array}$ \\
\hline Average wage per capita & & $\begin{array}{c}0.224 * * \\
(2.462)\end{array}$ & & $\begin{array}{c}0.246^{* * *} \\
(2.404)\end{array}$ & & $\begin{array}{c}0.205^{* * *} * \\
(2.607)\end{array}$ \\
\hline Government deficit/GDP & & $\begin{array}{c}-0.013 \\
(-0.016)\end{array}$ & & $\begin{array}{c}-0.018 \\
(-0.022)\end{array}$ & & $\begin{array}{c}0.191 \\
(0.306)\end{array}$ \\
\hline Marketization & & $\begin{array}{c}-0.148 \\
(-0.696)\end{array}$ & & $\begin{array}{c}-0.188 \\
(-0.904)\end{array}$ & & $\begin{array}{c}-0.214 \\
(-1.220)\end{array}$ \\
\hline FDI/GDP & & $\begin{array}{c}1.093 * * \\
(2.196)\end{array}$ & & $\begin{array}{c}1.013^{* *} \\
(2.028)\end{array}$ & & $\begin{array}{c}0.785 * * \\
(2.176)\end{array}$ \\
\hline Fiscal decentralization & & $\begin{array}{c}0.044 \\
(0.671)\end{array}$ & & $\begin{array}{c}0.054 \\
(0.829)\end{array}$ & & $\begin{array}{c}0.060 \\
(1.305)\end{array}$ \\
\hline Observations & 2,980 & 2,740 & 3,095 & 2,862 & 3,185 & 2,662 \\
\hline R-squared & 0.606 & 0.630 & 0.608 & 0.626 & 0.597 & 0.552 \\
\hline Number of cities & 246 & 246 & 256 & 254 & 263 & 256 \\
\hline Cragg-Donald F Statistic & & & & & 2317 & 1769 \\
\hline Hansen J statistic ( $\mathrm{p}$-value) & & & & & 0.170 & 0.368 \\
\hline
\end{tabular}

Note: The dependent variable is the log of the total land lease of the city. Huber-White robust t-statistics are in parentheses, where $* * * \mathrm{p}<0.01, * * \mathrm{p}<0.05, * \mathrm{p}<0.1$. The reduced sample does not include the capital city of each province; the PMC intensity represents the percentage of counties that have implemented the PMC fiscal reform in the total number of counties for a city; the instruments in the IV estimations include a dummy indicating whether a province has officially announced its decision to implement the PMC fiscal reform within its territory and two other dummies indicating whether a city contains at least one county that is defined by the central government as one of the major counties for producing grain or cotton, respectively. 
Table 7. Dynamic Effects of the PMC Fiscal Reform on City GDP Growth

\begin{tabular}{|c|c|c|c|c|c|}
\hline & $(1)$ & $(2)$ & $(3)$ & $(4)$ & $(5)$ \\
\hline \multirow[t]{2}{*}{5 years before } & -0.029 & 0.121 & 0.055 & 0.050 & 0.057 \\
\hline & $(-0.059)$ & $(0.222)$ & $(0.100)$ & $(0.090)$ & $(0.101)$ \\
\hline \multirow[t]{2}{*}{4 years before } & -0.330 & -0.439 & -0.548 & -0.575 & -0.524 \\
\hline & $(-0.736)$ & $(-0.994)$ & $(-1.223)$ & $(-1.285)$ & $(-1.171)$ \\
\hline \multirow[t]{2}{*}{3 years before } & -0.217 & -0.362 & -0.407 & -0.362 & -0.423 \\
\hline & $(-0.519)$ & $(-0.835)$ & $(-0.927)$ & $(-0.832)$ & $(-0.958)$ \\
\hline \multirow[t]{2}{*}{2 years before } & -0.197 & -0.237 & -0.339 & -0.261 & -0.276 \\
\hline & $(-0.425)$ & $(-0.490)$ & $(-0.686)$ & $(-0.531)$ & $(-0.549)$ \\
\hline \multirow[t]{2}{*}{1 year before } & 0.073 & 0.002 & -0.080 & 0.004 & 0.024 \\
\hline & $(0.155)$ & $(0.004)$ & $(-0.159)$ & $(0.008)$ & $(0.047)$ \\
\hline \multirow[t]{2}{*}{ Year of the PMC fiscal reform } & 0.335 & 0.310 & 0.204 & 0.213 & 0.174 \\
\hline & $(0.674)$ & $(0.595)$ & $(0.387)$ & $(0.410)$ & $(0.328)$ \\
\hline \multirow[t]{2}{*}{1 year after } & $1.092 * *$ & $0.789^{\dagger}$ & 0.695 & 0.671 & 0.658 \\
\hline & $(2.143)$ & $(1.453)$ & $(1.265)$ & $(1.231)$ & $(1.183)$ \\
\hline \multirow[t]{2}{*}{2 years after } & $1.231 * *$ & $1.074^{*}$ & $0.941^{\dagger}$ & $0.899^{\dagger}$ & $0.946^{\dagger}$ \\
\hline & $(2.256)$ & $(1.860)$ & (1.608) & $(1.554)$ & (1.603) \\
\hline \multirow[t]{2}{*}{3 years after } & $1.749 * * *$ & $1.577 * *$ & $1.464 * *$ & $1.337 * *$ & $1.292^{*}$ \\
\hline & $(2.854)$ & $(2.476)$ & $(2.266)$ & $(2.076)$ & $(1.953)$ \\
\hline \multirow[t]{2}{*}{4 years after } & $2.800 * * *$ & $2.613 * * *$ & $2.450 * * *$ & $2.373 * * *$ & $2.407 * * *$ \\
\hline & $(4.698)$ & $(4.017)$ & $(3.764)$ & $(3.669)$ & $(3.648)$ \\
\hline \multirow[t]{2}{*}{5 years after } & $2.471 * * *$ & $2.172 * * *$ & $2.047 * *$ & $1.944 * *$ & $1.997 * *$ \\
\hline & $(3.391)$ & $(2.723)$ & $(2.585)$ & $(2.455)$ & $(2.482)$ \\
\hline \multirow[t]{2}{*}{6 years after } & $2.753 * * *$ & $2.316 * * *$ & $2.183 * * *$ & $2.021 * * *$ & $2.145 * * *$ \\
\hline & $(4.293)$ & $(3.344)$ & $(3.170)$ & $(2.925)$ & $(3.075)$ \\
\hline \multirow[t]{2}{*}{7 years after } & $3.367 * * *$ & $2.928 * * *$ & $2.744 * * *$ & $2.623 * * *$ & $2.767 * * *$ \\
\hline & $(4.993)$ & $(4.162)$ & $(3.962)$ & $(3.754)$ & $(3.956)$ \\
\hline \multirow[t]{2}{*}{ Total land lease } & & & $0.324 * *$ & $0.274^{*}$ & 0.257 \\
\hline & & & $(2.124)$ & $(1.809)$ & $(1.627)$ \\
\hline \multirow[t]{2}{*}{ Capital Investment } & & & & $2.136 * * *$ & $1.989 * * *$ \\
\hline & & & & $(3.284)$ & $(2.929)$ \\
\hline \multirow[t]{2}{*}{ FDI/GDP } & & & & & $9.356 * * *$ \\
\hline & & & & & $(4.602)$ \\
\hline Other controls & No & Yes & Yes & Yes & Yes \\
\hline Observations & 3,289 & 3,054 & 3,005 & 3,001 & 2,911 \\
\hline R-squared & 0.259 & 0.298 & 0.299 & 0.303 & 0.310 \\
\hline Number of cities & 267 & 263 & 263 & 263 & 263 \\
\hline
\end{tabular}

Note: The dependent variable is the city GDP growth rate. Huber-White robust t-statistics are in parentheses, where $* * * \mathrm{p}<0.01, * * \mathrm{p}<0.05, * \mathrm{p}<0.1$ and where ${ }^{\dagger}$ represents significance at the $10 \%$ level under a one-tail test. 
Table 8. Dynamic Effects of the PMC Fiscal Reform on City Land Lease

\begin{tabular}{|c|c|c|c|c|c|}
\hline & (1) & (2) & (3) & (4) & (5) \\
\hline \multirow[t]{2}{*}{5 years before } & $0.152 * *$ & 0.092 & 0.089 & 0.090 & 0.074 \\
\hline & $(2.224)$ & (1.334) & (1.299) & (1.302) & (1.108) \\
\hline \multirow[t]{2}{*}{4 years before } & -0.010 & -0.052 & -0.063 & -0.067 & -0.077 \\
\hline & $(-0.134)$ & $(-0.675)$ & $(-0.795)$ & $(-0.846)$ & $(-0.981)$ \\
\hline \multirow[t]{2}{*}{3 years before } & 0.061 & 0.013 & 0.015 & 0.016 & 0.010 \\
\hline & $(0.902)$ & $(0.196)$ & $(0.225)$ & $(0.243)$ & $(0.158)$ \\
\hline \multirow[t]{2}{*}{2 years before } & 0.091 & 0.032 & 0.032 & 0.033 & 0.021 \\
\hline & (1.276) & $(0.450)$ & $(0.458)$ & $(0.471)$ & $(0.296)$ \\
\hline \multirow[t]{2}{*}{1 year before } & 0.089 & 0.042 & 0.049 & 0.047 & 0.047 \\
\hline & $(1.185)$ & $(0.557)$ & $(0.658)$ & $(0.642)$ & $(0.629)$ \\
\hline \multirow{2}{*}{$\begin{array}{l}\text { Year of the PMC fiscal } \\
\text { reform }\end{array}$} & $0.191 * *$ & $0.141^{*}$ & $0.146^{*}$ & $0.147 *$ & $0.121^{\dagger}$ \\
\hline & $(2.318)$ & $(1.753)$ & (1.823) & (1.864) & (1.553) \\
\hline \multirow[t]{2}{*}{1 year after } & $0.192 * *$ & $0.138^{*}$ & $0.142^{*}$ & $0.132 *$ & $0.135^{*}$ \\
\hline & $(2.365)$ & $(1.754)$ & $(1.831)$ & $(1.746)$ & (1.749) \\
\hline \multirow[t]{2}{*}{2 years after } & $0.276 * * *$ & $0.223 * *$ & $0.227 * *$ & $0.225 * * *$ & $0.248 * * *$ \\
\hline & $(2.965)$ & $(2.476)$ & $(2.554)$ & $(2.598)$ & $(2.802)$ \\
\hline \multirow[t]{2}{*}{3 years after } & $0.270 * * *$ & $0.203 * *$ & $0.211 * *$ & $0.203 * *$ & $0.218 * *$ \\
\hline & $(2.701)$ & $(2.105)$ & $(2.198)$ & $(2.177)$ & $(2.305)$ \\
\hline \multirow[t]{2}{*}{4 years after } & $0.444 * * *$ & $0.380 * * *$ & $0.389 * * *$ & $0.381 * * *$ & $0.415^{* * *}$ \\
\hline & $(4.358)$ & $(3.860)$ & $(4.007)$ & $(4.037)$ & $(4.305)$ \\
\hline \multirow[t]{2}{*}{5 years after } & $0.310 * * *$ & $0.260 * *$ & $0.278 * *$ & $0.266^{* *}$ & $0.285 * *$ \\
\hline & $(2.653)$ & $(2.287)$ & $(2.452)$ & $(2.399)$ & $(2.448)$ \\
\hline \multirow[t]{2}{*}{6 years after } & $0.385 * * *$ & $0.352 * * *$ & $0.360 * * *$ & $0.342 * * *$ & $0.370 * * *$ \\
\hline & $(3.160)$ & $(2.971)$ & $(3.051)$ & $(2.968)$ & $(3.074)$ \\
\hline \multirow[t]{2}{*}{7 years after } & $0.598 * * *$ & $0.539 * * *$ & $0.549 * * *$ & $0.530 * * *$ & $0.570^{* * *} *$ \\
\hline & $(4.502)$ & $(4.089)$ & $(4.154)$ & $(4.077)$ & $(4.226)$ \\
\hline Other controls & No & Yes & Yes & Yes & Yes \\
\hline Observations & 3,232 & 3,044 & 3,036 & 3,029 & 2,931 \\
\hline R-squared & 0.595 & 0.617 & 0.617 & 0.619 & 0.625 \\
\hline Number of cities & 267 & 263 & 262 & 262 & 262 \\
\hline
\end{tabular}

Note: The dependent variable is the log of the total land lease of the city. Huber-White robust t-statistics are in parentheses, where $* * * \mathrm{p}<0.01, * * \mathrm{p}<0.05, * \mathrm{p}<0.1$. Through Columns (2) to (5), we add to the model different control variables continuously in the same order as that in Table 4. 
Table 9. Heterogeneous Effects of the PMC Fiscal Reform on City GDP Growth

\begin{tabular}{|c|c|c|c|c|c|}
\hline & (1) & (2) & (3) & (4) & (5) \\
\hline PMC fiscal reform & $\begin{array}{l}1.545 * * \\
(2.503)\end{array}$ & $\begin{array}{l}1.082 * \\
(1.737)\end{array}$ & $\begin{array}{l}1.064 * \\
(1.722)\end{array}$ & $\begin{array}{l}1.033^{*} \\
(1.689)\end{array}$ & $\begin{array}{l}1.139 * \\
(1.821)\end{array}$ \\
\hline Rich level of the city & $\begin{array}{l}-2.681 \\
(-1.359)\end{array}$ & $\begin{array}{l}-1.430 \\
(-0.752)\end{array}$ & $\begin{array}{l}-1.551 \\
(-0.809)\end{array}$ & $\begin{array}{l}-0.926 \\
(-0.480)\end{array}$ & $\begin{array}{c}0.696 \\
(0.394)\end{array}$ \\
\hline PMC $\times$ Rich level & $\begin{array}{l}-1.573^{f} \\
(-1.254)\end{array}$ & $\begin{array}{l}-0.730^{5} \\
(-0.569)\end{array}$ & $\begin{array}{l}-0.693^{f} \\
(-0.543)\end{array}$ & $\begin{array}{l}-0.871^{f} \\
(-0.684)\end{array}$ & $\begin{array}{l}-1.204^{+} \\
(-0.927)\end{array}$ \\
\hline Total land lease & & & $\begin{array}{l}0.214 * * \\
(2.310)\end{array}$ & $\begin{array}{l}0.188 * * \\
(2.067)\end{array}$ & $\begin{array}{l}0.168 * \\
(1.804)\end{array}$ \\
\hline Capital Investment & & & & $\begin{array}{c}2.446 * * * \\
(3.745)\end{array}$ & $\begin{array}{c}2.298 * * * \\
(3.361)\end{array}$ \\
\hline FDI/GDP & & & & & $\begin{array}{c}9.733^{* * *} \\
(4.335)\end{array}$ \\
\hline GDP per capita & & $\begin{array}{c}-2.563 * * * \\
(-3.237)\end{array}$ & $\begin{array}{c}-2.638 * * * \\
(-3.315)\end{array}$ & $\begin{array}{c}-2.431 * * * \\
(-2.998)\end{array}$ & $\begin{array}{c}-2.419 * * * \\
(-2.922)\end{array}$ \\
\hline Agricultural sector/GDP & & $\begin{array}{c}-0.133 * * * \\
(-3.072)\end{array}$ & $\begin{array}{c}-0.132 * * * \\
(-3.062)\end{array}$ & $\begin{array}{c}-0.115 * * * \\
(-2.770)\end{array}$ & $\begin{array}{c}-0.116 * * * \\
(-2.751)\end{array}$ \\
\hline Economic agglomeration & & $\begin{array}{c}0.752 * * \\
(2.302)\end{array}$ & $\begin{array}{l}0.785^{* *} \\
(2.399)\end{array}$ & $\begin{array}{c}0.756^{* *} \\
(2.334)\end{array}$ & $\begin{array}{l}0.726^{* *} \\
(2.209)\end{array}$ \\
\hline Population growth & & $\begin{array}{c}-0.040 \\
(-1.138)\end{array}$ & $\begin{array}{c}-0.039 \\
(-1.106)\end{array}$ & $\begin{array}{c}-0.048 \\
(-1.374)\end{array}$ & $\begin{array}{c}-0.047 \\
(-1.275)\end{array}$ \\
\hline Inflation & & $\begin{array}{c}-0.286 * * \\
(-2.537)\end{array}$ & $\begin{array}{c}-0.285^{* *} \\
(-2.539)\end{array}$ & $\begin{array}{l}-0.260 * * \\
(-2.328)\end{array}$ & $\begin{array}{l}-0.253 * * \\
(-2.108)\end{array}$ \\
\hline $\begin{array}{l}\text { Government } \\
\text { expenditure/GDP }\end{array}$ & & $\begin{array}{c}11.229 * * * \\
(4.880)\end{array}$ & $\begin{array}{c}11.101 * * * \\
(4.884)\end{array}$ & $\begin{array}{c}9.040 * * * \\
(3.983)\end{array}$ & $\begin{array}{c}8.955^{* * *} * \\
(3.403)\end{array}$ \\
\hline $\begin{array}{l}\text { Observations } \\
\text { R-squared } \\
\text { Number of cities }\end{array}$ & $\begin{array}{c}3,192 \\
0.256 \\
263\end{array}$ & $\begin{array}{c}3,018 \\
0.287 \\
261\end{array}$ & $\begin{array}{c}3,018 \\
0.288 \\
261\end{array}$ & $\begin{array}{c}3,014 \\
0.295 \\
261\end{array}$ & $\begin{array}{c}2,923 \\
0.301 \\
261\end{array}$ \\
\hline
\end{tabular}

Note: The dependent variable is the city GDP growth rate. Huber-White robust t-statistics are in parentheses, where $* * * \mathrm{p}<0.01,{ }^{*} \mathrm{p}<0.05,{ }^{*} \mathrm{p}<0.1$, where ${ }^{\dagger}$ represents significance at the $10 \%$ level under a one-tail test, and where ${ }^{*}$ represents that the variable is jointly significant at the $5 \%$ level. 
Table 10. Heterogeneous Effects of the PMC Fiscal Reform on City Land Lease

\begin{tabular}{|c|c|c|c|c|c|}
\hline & (1) & (2) & (3) & (4) & (5) \\
\hline \multirow[t]{2}{*}{ PMC fiscal reform } & $0.266^{* * *}$ & $0.318^{* * *}$ & $0.331 * * *$ & $0.310 * * *$ & $0.332 * * *$ \\
\hline & $(2.671)$ & $(3.436)$ & $(3.592)$ & $(3.417)$ & (3.773) \\
\hline \multirow[t]{2}{*}{ Rich level of the city } & 0.076 & 0.236 & -0.397 & -0.335 & -0.295 \\
\hline & $(0.207)$ & $(0.646)$ & $(-0.858)$ & $(-0.723)$ & $(-0.635)$ \\
\hline \multirow[t]{2}{*}{ PMC $\times$ Rich level } & $-0.298^{\dagger}$ & $-0.470 * *$ & $-0.482 * *$ & $-0.443 * *$ & $-0.502 * * *$ \\
\hline & $(-1.408)$ & $(-2.498)$ & $(-2.581)$ & $(-2.372)$ & $(-2.776)$ \\
\hline \multirow[t]{2}{*}{ GDP per capita } & & $0.480 * * *$ & $0.620 * * *$ & $0.600 * * *$ & $0.558 * * *$ \\
\hline & & $(3.362)$ & $(3.770)$ & $(3.653)$ & $(3.201)$ \\
\hline \multirow[t]{2}{*}{ Agricultural sector/GDP } & & 0.000 & -0.003 & -0.003 & -0.005 \\
\hline & & $(0.060)$ & $(-0.475)$ & $(-0.427)$ & $(-0.735)$ \\
\hline \multirow[t]{2}{*}{ Total population } & & & $0.427 * *$ & $0.408 * *$ & $0.528 * *$ \\
\hline & & & $(2.094)$ & (1.986) & $(2.542)$ \\
\hline \multirow[t]{2}{*}{ Cultivation land per capita } & & & -0.070 & -0.064 & -0.074 \\
\hline & & & $(-1.357)$ & $(-1.259)$ & $(-1.462)$ \\
\hline \multirow[t]{2}{*}{ Average wage per capita } & & & & $0.243 * * *$ & $0.221 * *$ \\
\hline & & & & $(2.605)$ & $(2.492)$ \\
\hline \multirow[t]{2}{*}{ Government deficit/GDP } & & & & 0.421 & 0.111 \\
\hline & & & & $(0.730)$ & $(0.140)$ \\
\hline \multirow[t]{2}{*}{ Marketization } & & & & & -0.148 \\
\hline & & & & & $(-0.716)$ \\
\hline \multirow{2}{*}{ FDI/GDP } & & & & & $0.956 * *$ \\
\hline & & & & & $(2.071)$ \\
\hline \multirow[t]{2}{*}{ Fiscal decentralization } & & & & & 0.060 \\
\hline & & & & & $(0.949)$ \\
\hline Observations & 3,143 & 3,012 & 3,009 & 3,002 & 2,904 \\
\hline R-squared & 0.595 & 0.617 & 0.618 & 0.620 & 0.626 \\
\hline Number of cities & 263 & 261 & 260 & 260 & 260 \\
\hline
\end{tabular}

Note: The dependent variable is the log of the total land lease of the city. Huber-White robust t-statistics are in parentheses, where $* * * \mathrm{p}<0.01, * * \mathrm{p}<0.05, * \mathrm{p}<0.1$ and where ${ }^{\dagger}$ represents significance at the $10 \%$ level under a one-tail test. 
Figure 1. Ratio of Land Lease Revenue to Total Subnational Budgetary Revenue or Expenditure

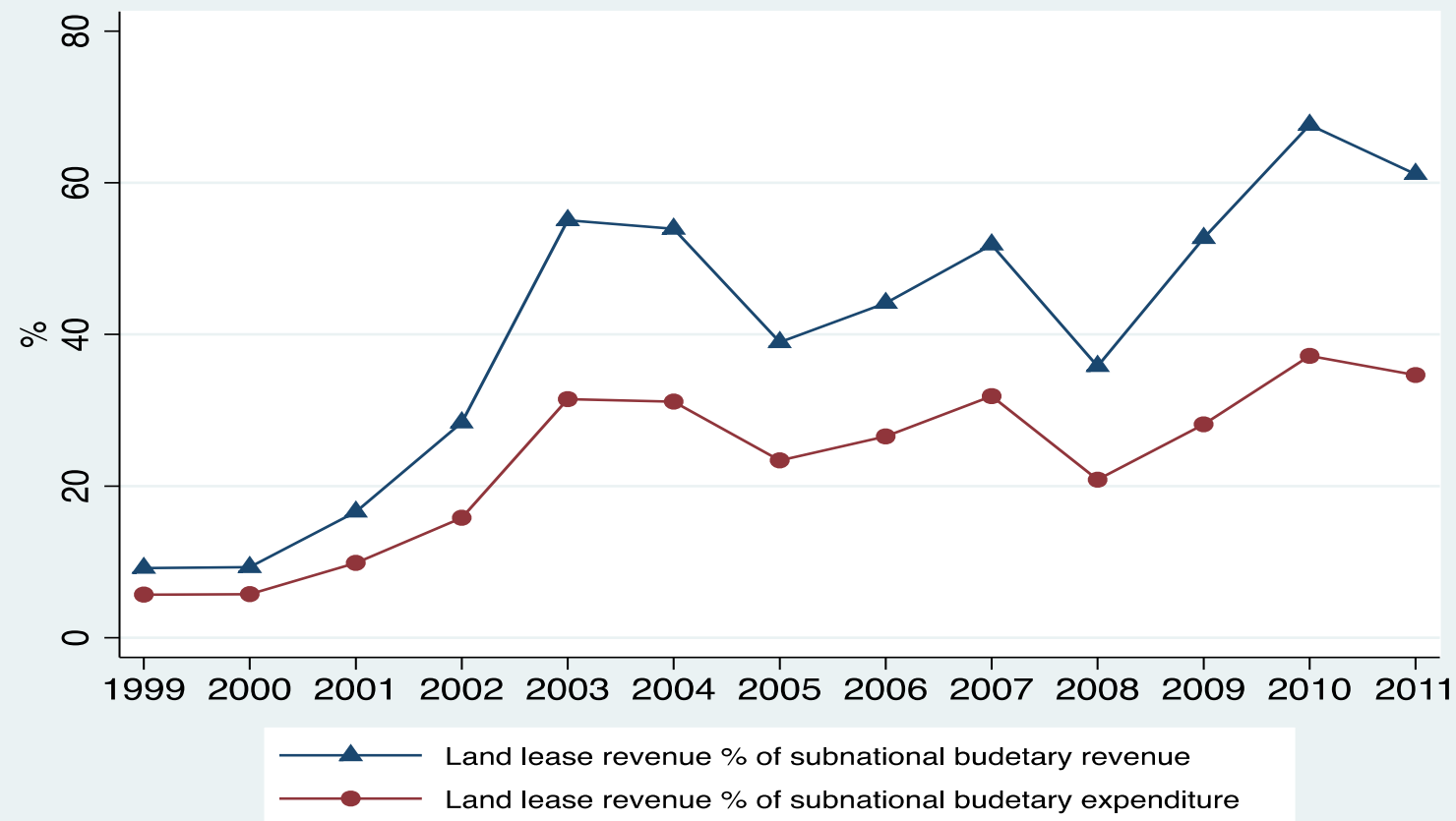

Source: China Statistical Yearbook and China Land and Resources Yearbook, 2000-2012.

Figure 2. Introduction of the PMC Fiscal Reform in China

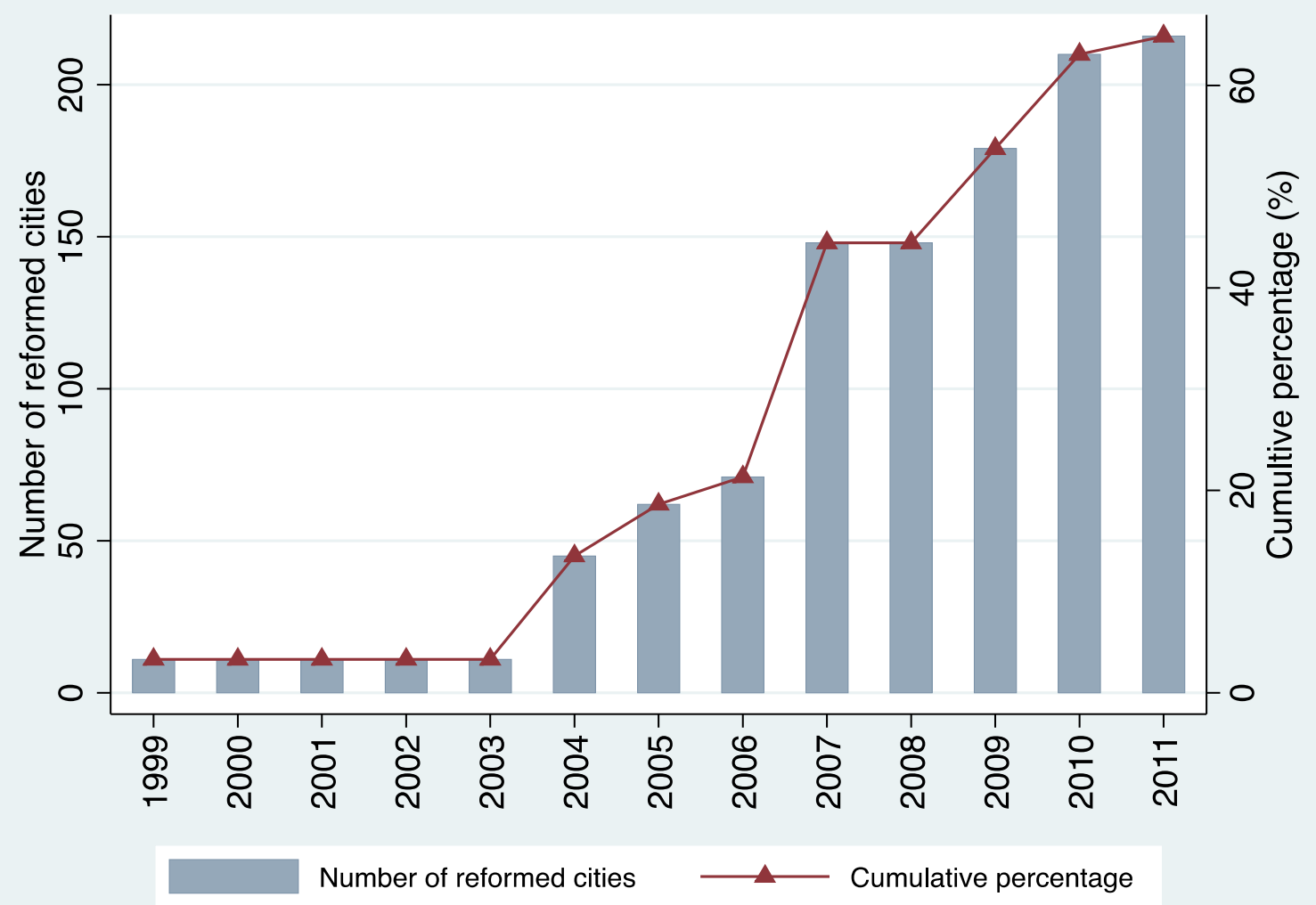

Source: Official documents released by provincial governments, various years. 
Figure 3. Trends in GDP Growth of Chinese Cities

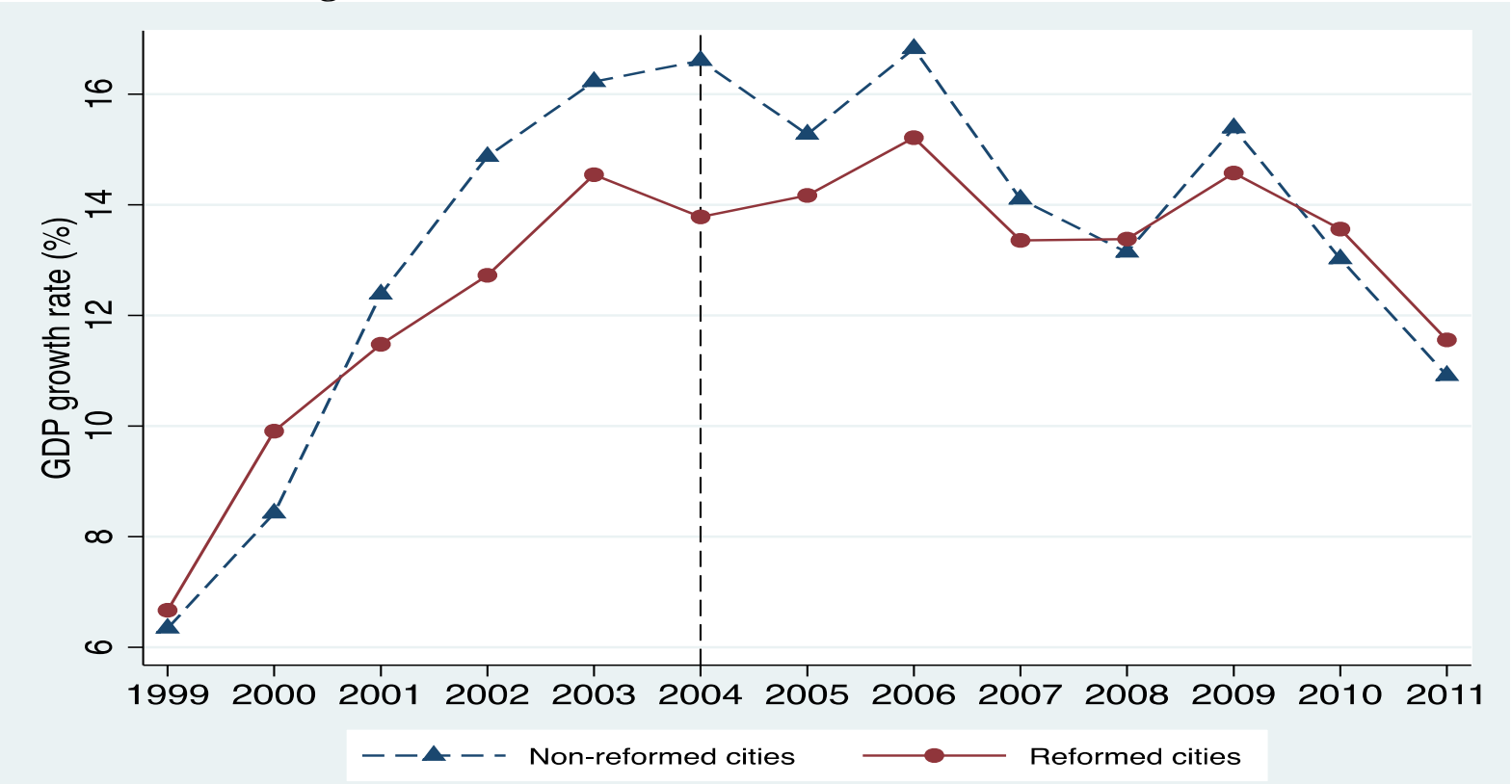

Note: Reformed cities refer to those cities that implemented the PMC fiscal reform by the end of 2011; non-reformed cities are those cities that have not implemented the reform throughout the whole period in our sample.

Source: China City Statistical Yearbook, 2000-2012.

Figure 4. Trends in Land Leasing of Chinese Cities

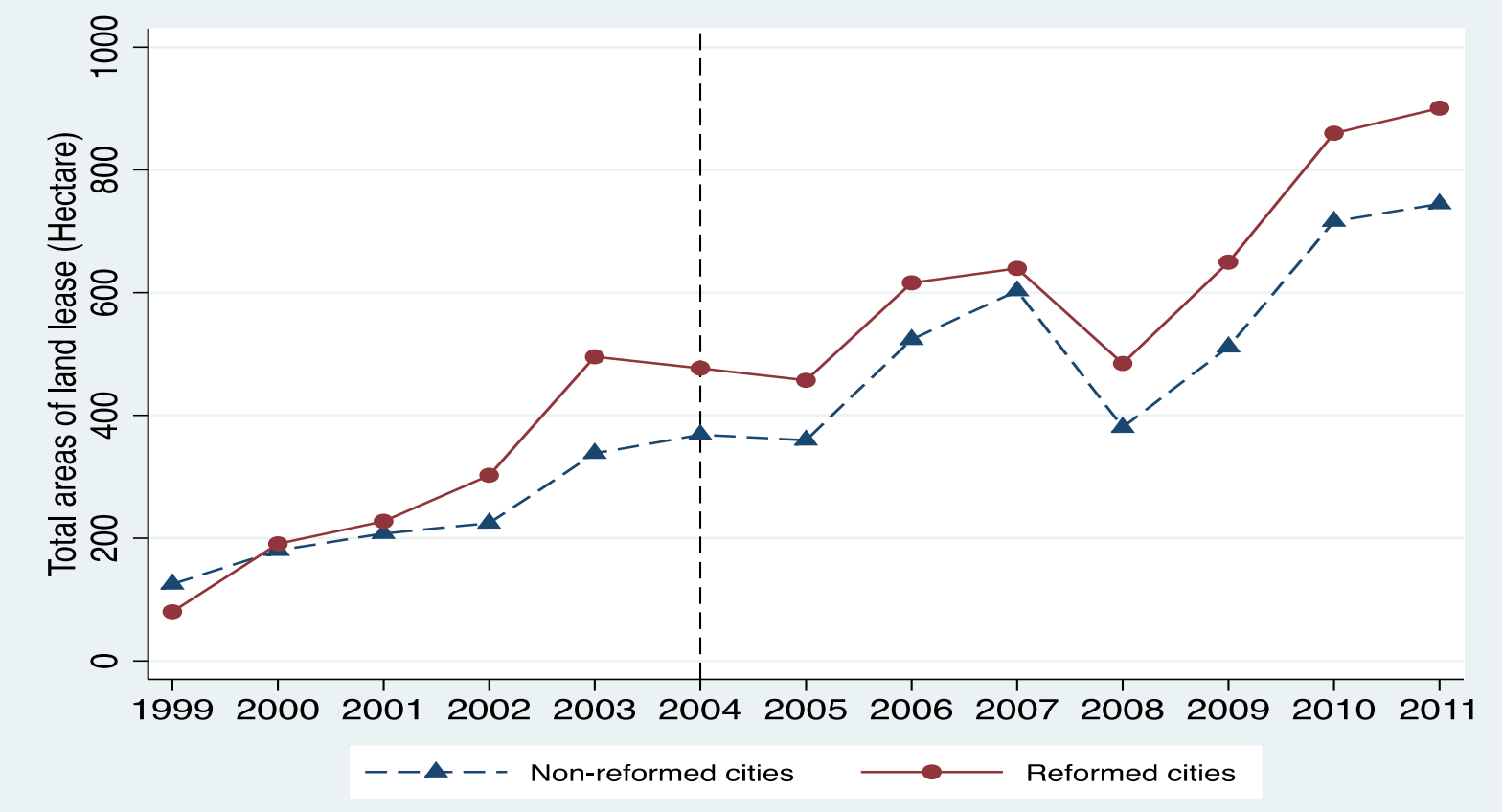

Note: Reformed cities refer to those cities that have ever implemented the PMC fiscal reform by the end of 2011; non-reformed cities are those cities that have not implemented the reform throughout the whole period in our sample.

Source: China City Statistical Yearbook, 2000-2012. 


\section{Appendix}

Table A1. Economic Growth Equation: Test for Common Pre-treatment Trends

\begin{tabular}{lccccc}
\hline & $(1)$ & $(2)$ & $(3)$ & $(4)$ & $(5)$ \\
\hline 2000 dummy & 1.199 & $1.878^{*}$ & $1.834^{*}$ & $1.792^{*}$ & $1.869^{* *}$ \\
& $(1.351)$ & $(1.939)$ & $(1.914)$ & $(1.879)$ & $(1.970)$ \\
2001 dummy & $4.980^{* * *}$ & $5.442^{* * *}$ & $5.254^{* * *}$ & $5.220^{* * *}$ & $5.111^{* * *}$ \\
& $(5.677)$ & $(5.769)$ & $(5.600)$ & $(5.607)$ & $(5.691)$ \\
2002 dummy & $7.220^{* * *}$ & $7.727^{* * *}$ & $7.465 * * *$ & $7.402^{* * *}$ & $7.612^{* * *}$ \\
& $(7.775)$ & $(7.954)$ & $(7.592)$ & $(7.603)$ & $(7.813)$ \\
2003 dummy & $8.410^{* * *}$ & $9.643^{* * *}$ & $9.294 * * *$ & $9.114^{* * *}$ & $9.258^{* * *}$ \\
& $(8.913)$ & $(8.632)$ & $(8.262)$ & $(8.064)$ & $(8.302)$ \\
2000 dummy*treated & 1.691 & 1.345 & 1.317 & 1.351 & 1.376 \\
& $(1.487)$ & $(1.163)$ & $(1.132)$ & $(1.164)$ & $(1.187)$ \\
2001 dummy*treated & -0.244 & -0.329 & -0.316 & -0.325 & -0.042 \\
& $(-0.228)$ & $(-0.311)$ & $(-0.299)$ & $(-0.307)$ & $(-0.040)$ \\
2002 dummy*treated & -1.188 & -1.481 & -1.485 & -1.473 & -1.502 \\
& $(-1.068)$ & $(-1.381)$ & $(-1.381)$ & $(-1.381)$ & $(-1.414)$ \\
2003 dummy*treated & -0.699 & -1.340 & -1.366 & -1.356 & -1.284 \\
& $(-0.621)$ & $(-1.194)$ & $(-1.215)$ & $(-1.211)$ & $(-1.162)$ \\
Other controls & No & Yes & Yes & Yes & Yes \\
Observations & 1,168 & 1,123 & 1,123 & 1,122 & 1,122 \\
R-squared & 0.327 & 0.358 & 0.359 & 0.361 & 0.368 \\
Number of cities & 266 & 260 & 260 & 260 & 260 \\
\hline Note: The depend
\end{tabular}

Note: The dependent variable is the city GDP growth rate. Huber-White robust t-statistics are in parentheses, where $* * * \mathrm{p}<0.01, * * \mathrm{p}<0.05, * \mathrm{p}<0.1$. Through Columns (2) to (5), we add to the model different control variables continuously in the same order as that in Table 3.

Table A2. Land Expansion Equation: Test for Common Pre-treatment Trends

\begin{tabular}{lccccc}
\hline & $(1)$ & $(2)$ & $(3)$ & $(4)$ & $(5)$ \\
\hline 2000 dummy & 0.214 & 0.094 & 0.208 & 0.226 & 0.230 \\
& $(0.707)$ & $(0.304)$ & $(0.732)$ & $(0.786)$ & $(0.813)$ \\
2001 dummy & $0.921^{* * *}$ & $0.827 * * *$ & $0.821^{* * *}$ & $0.840^{* * *}$ & $0.776^{* * *}$ \\
& $(3.682)$ & $(2.936)$ & $(3.353)$ & $(3.386)$ & $(3.257)$ \\
2002 dummy & $1.452^{* * *}$ & $1.290^{* * *}$ & $1.226 * * *$ & $1.258 * * *$ & $1.221^{* * *}$ \\
& $(6.061)$ & $(4.751)$ & $(4.317)$ & $(4.276)$ & $(4.042)$ \\
2003 dummy & $1.852^{* * *}$ & $1.609 * * *$ & $1.543 * * *$ & $1.554 * * *$ & $1.458^{* * *}$ \\
& $(8.501)$ & $(6.441)$ & $(5.461)$ & $(5.338)$ & $(4.812)$ \\
2000 dummy*treated & 0.058 & 0.153 & 0.007 & -0.022 & -0.022 \\
& $(0.178)$ & $(0.462)$ & $(0.022)$ & $(-0.070)$ & $(-0.071)$ \\
2001 dummy*treated & -0.099 & -0.084 & -0.178 & -0.192 & -0.128 \\
& $(-0.365)$ & $(-0.293)$ & $(-0.727)$ & $(-0.794)$ & $(-0.544)$ \\
2002 dummy*treated & -0.051 & -0.007 & -0.105 & -0.118 & -0.123 \\
& $(-0.200)$ & $(-0.027)$ & $(-0.394)$ & $(-0.442)$ & $(-0.457)$ \\
2003 dummy*treated & 0.012 & 0.111 & -0.078 & -0.062 & -0.040 \\
& $(0.050)$ & $(0.472)$ & $(-0.323)$ & $(-0.260)$ & $(-0.165)$ \\
Other controls & No & Yes & Yes & Yes & Yes \\
Observations & 1,178 & 1,149 & 1,115 & 1,111 & 1,110 \\
R-squared & 0.397 & 0.399 & 0.418 & 0.422 & 0.432 \\
Number of cities & 266 & 263 & 260 & 259 & 259 \\
\hline Note: The & &
\end{tabular}

Note: The dependent variable is the total land lease of the city. Huber-White robust t-statistics are in parentheses, where *** $\mathrm{p}<0.01, * * \mathrm{p}<0.05, * \mathrm{p}<0.1$. Through Columns (2) to (5), we add to the model different control variables continuously in the same order as that in Table 4. 